\title{
Radiocarbon Chronologies and Extinction Dynamics of the Late Quaternary Mammalian Megafauna of the Taimyr Peninsula, Russian Federation
}

\author{
Ross D. E. MacPhee \\ Division of Vertebrate Zoology/Mammalogy, American Museum of Natural History, New York, NY 10024, U.S.A.
}

\author{
Alexei N. Tikhonov \\ Zoological Institute, Russian Academy of Sciences, Laboratory of Mammals, Universitetskaya nab. 1, 199034, \\ St. Petersburg, Russia
}

Dick Mol

CERPOLEXIMammuthus, Gudumholm 41, NL-2133 HG Hoofddorp, The Netherlands

\section{Christian de Marliave}

CERPOLEXIMammuthus, 2, Avenue de la Pelouse, F-94160, Saint-Mande, France

Hans van der Plicht

Center for Isotope Research, University of Groningen, Nijenborgh 4, NL-9747 AG Groningen, The Netherlands

\author{
Alex D. Greenwood* and Clare Flemming \\ Division of Vertebrate Zoology/Mammalogy, American Museum of Natural History, New York, NY 10024, U.S.A.
}

Larry Agenbroad

Department of Geology, Northern Arizona University, NAU Box 4099, Flagstaff, AZ 86011, U.S.A.

(Received 4 October 2001, revised manuscript accepted 28 November 2001)

\begin{abstract}
This paper presents 75 new radiocarbon dates based on late Quaternary mammal remains recovered from eastern Taimyr Peninsula and adjacent parts of the northern Siberian lowlands, Russian Federation, including specimens of woolly mammoth (Mammuthus primigenius), steppe bison (Bison priscus), muskox (Ovibos moschatus), moose (Alces alces), reindeer (Rangifer tarandus), horse (Equus caballus) and wolf (Canis lupus). New evidence permits reanalysis of megafaunal extinction dynamics in the Asian high Arctic periphery. Increasingly, radiometric records of individual species show evidence of a gap at or near the Pleistocene/Holocene boundary (PHB). In the past, the PHB gap was regarded as significant only when actually terminal, i.e., when it marked the apparent "last" occurrence of a species (e.g., current "last" occurrence date for woolly mammoth in mainland Eurasia is $9600 \mathrm{yr}$ BP). However, for high Arctic populations of horses and muskoxen the gap marks an interruption rather than extinction, because their radiocarbon records resume, nearly simultaneously, much later in the Holocene. Taphonomic effects, $\Delta \mathrm{C}^{14}$ flux, and biased sampling are unlikely explanations for these hiatuses. A possible explanation is that the gap is the signature of an event, of unknown nature, that prompted the nearly simultaneous crash of many megafaunal populations in the high Arctic and possibly elsewhere in Eurasia.

(C) 2002 Elsevier Science Ltd. All rights reserved.
\end{abstract}

Keywords: MEGAFAUNAL EXTINCTION, RADIOCARBON DATING, RUSSIAN FEDERATION, QUATERNARY.

*Present address: GSF-Forschungszentrum Für Umwelt und Gesundheit, GmbH, Ingolstädter Lardstr. 1, D-85764 Neuherberg, Germany. 


\section{Introduction}

\section{Radiocarbon chronologies and species histories}

A $\mathrm{t}$ present, the Asian portion of the high Arctic periphery (i.e., mainland north of $\sim 66^{\circ} \mathrm{N}$, plus the continental shelf and islands in the Arctic Sea) supports only two species of herbivorous megafaunal mammals - reindeer (Rangifer tarandus), both wild and domesticated, and muskox (Ovibos moschatus) reintroduced from Canada and Alaska in the 1970s (Lent, 1999). It was not always thus. Several thousand years ago, this same zone supported at least a halfdozen large herbivores (Sher, 1974; Vereshchagin \& Baryshnikov, 1984; Kahlke, 1994, 1999). Some (e.g., Mammuthus primigenius, Bison priscus) became extinct on the mainland near the Pleistocene/Holocene boundary (PHB), perhaps as part of the Eurasian equivalent of the end-Pleistocene extinctions which affected the continental New World slightly earlier (for discussion of putative causes, see Graham \& Lundelius, 1984; Agenbroad, 1984; MacPhee \& Marx, 1997; Martin \& Steadman, 1999; Alroy, 2001). Others, like Asian $O$. moschatus, also disappear from the record at about the same time, only to reappear-briefly - thousands of years later. Was there a single, temporally constrained event that provoked the loss of many, but clearly not all, of the Holarctic megafauna? Or was it rather a case of separate responses to separate factors, with some species suffering complete extinction while others were unaffected or experienced local extirpation only? Or are these apparent patterns simply artefacts of an imperfect radiocarbon record?

To answer such questions, presence/absence data on individual species are necessary but not sufficient, because information on populations across time is also needed. Some headway in understanding the population dynamics of now-extinct species in different parts of the globe is being made through an array of novel techniques and applications (e.g., Fisher, 1996; Culver et al., 2000; Greenwood et al., 2001), and there is hope that molecular investigations of continuity and change in gene distributions will eventually offer intriguing insights into species' histories during the last part of the Quaternary (e.g., Vilà et al., 2001). However, it is important not to lose sight of the fact that the scaffolding on which all historical investigations hang is time. Without a dependable chronometric record, process becomes obscured or uninterpretable. In Quaternary studies, it is the radiocarbon record that has played, and will no doubt continue to play, a pivotal role not only in defining in general terms when Quaternary extinctions took place, but also in revealing whether or not individual extinctions were temporally coordinated in those places where large losses occurred (Faunmap Working Group, 1996; Beck, 1996; Martin \& Steadman, 1999; MacPhee et al., 1999; Grayson, 2001).

Another aspect of the radiocarbon record is that it may also supply useful diachronic information on species composition and change in a given area. The causes and consequences of population fluctuation are questions of fundamental importance in animal ecology, but relevant modern studies are usually limited in time depth to a few decades (e.g., Berger et al., 2001; Jackson et al., 2001; Bjornstad \& Grenfell, 2001). Admittedly, techniques for examining population dynamics over much longer intervals, such as the one contemplated here, are crude at present. Nevertheless, any reliable information concerning this topic may help to elucidate why so many megafaunal species have disappeared in geologically recent times (Graham \& Lundelius, 1984; MacPhee \& Marx, 1997; MacPhee \& Flemming, 1999; Martin \& Steadman, 1999; Alroy, 2001).

In this paper we are principally concerned with the history of mammalian megafauna on the Taimyr Peninsula and the adjacent northern Siberian lowlands (Figure 1(a)-(b)) during the latest part of the Quaternary, i.e., after the Last Glacial Maximum (LGM). Our primary tool for this purpose is the current radiocarbon record for Taimyr, which we have been able to substantially augment with 75 separate age assessments (67 dates on isolated fossils and eight weighted averages for multiply-dated specimens or individuals; Tables 1-3; Figure 2(a)-(d)). This new date pool is based on samples selected for dating from the extensive fossil collections made by members of the Cerpolex/ Mammuthus Expedition (hereafter, CME) in 19992000, mostly in the eastern half of Taimyr. Our chief concern here is to place these new dates within the context of similar date pools collated in other recent publications (see, especially, Sulerzhitsky, 1995; Sulerzhitsky \& Romanenko, 1997, 1999; Vasil'chuk et al., 1997; Orlova et al., 2000).

The Taimyr Peninsula has long been of interest to Quaternary paleontologists because at least some elements of the now-extinct megafauna appear to have survived there and in nearby regions somewhat longer than they did elsewhere on the mainland (i.e., the Eurasian continent as it exists today, without regard to connections that may have existed at times of lowered sea level). For example, the latest dates for woolly mammoths anywhere in mainland Eurasia are based on specimens from the Taimyr and nearby Yamal peninsulas (Sulerzhitsky, 1995; this paper). (The latest records of all are for Wrangel Island in the East Siberian Sea, where mammoths survived until c. $3700 \mathrm{yr}$ BP (Vartanyan et al., 1993, 1995; Lister, 1993; Reumer \& Mol, 2001).) Taimyr has also yielded "last" occurrence dates for several other species or distinct populations (Bison priscus, north Asian Equus "lenensis" [=E. caballus], and Asian Ovibos moschatus). This suggests that this area is of prime importance for investigating megafaunal extinction dynamics in northern Eurasia. Additional resolution will depend on gathering many more megafaunal dates, especially for species other than Mammuthus primigenius. 


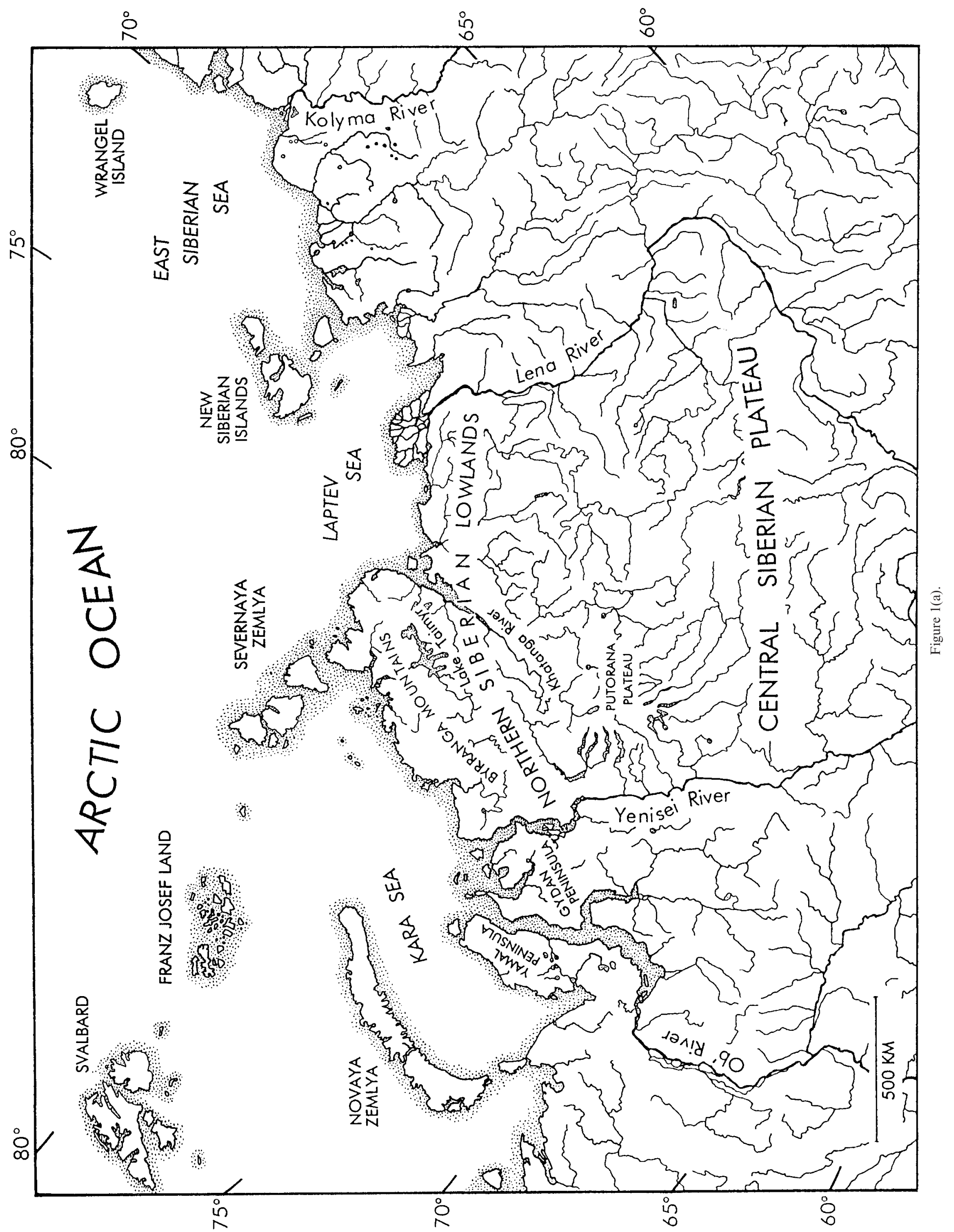




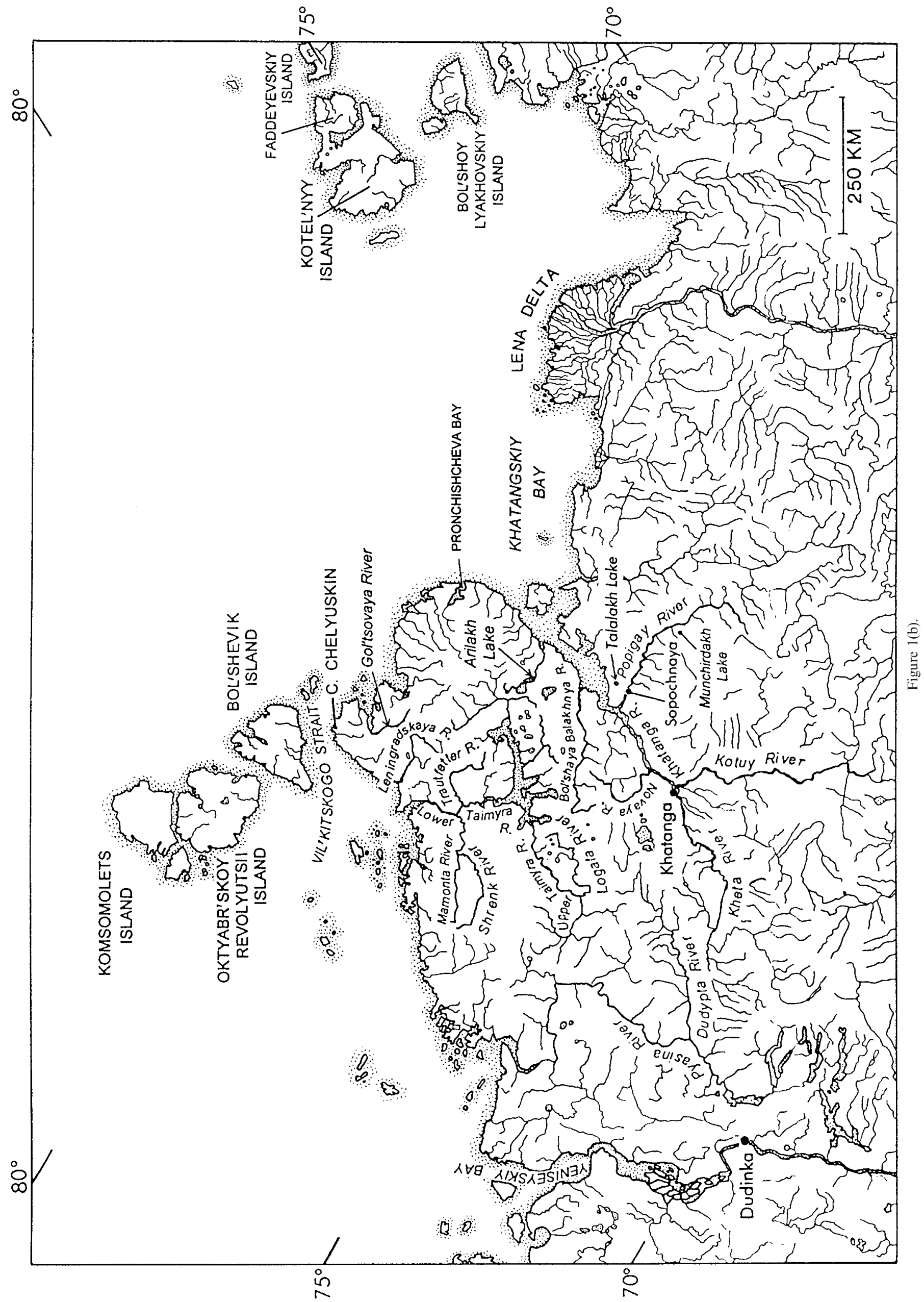




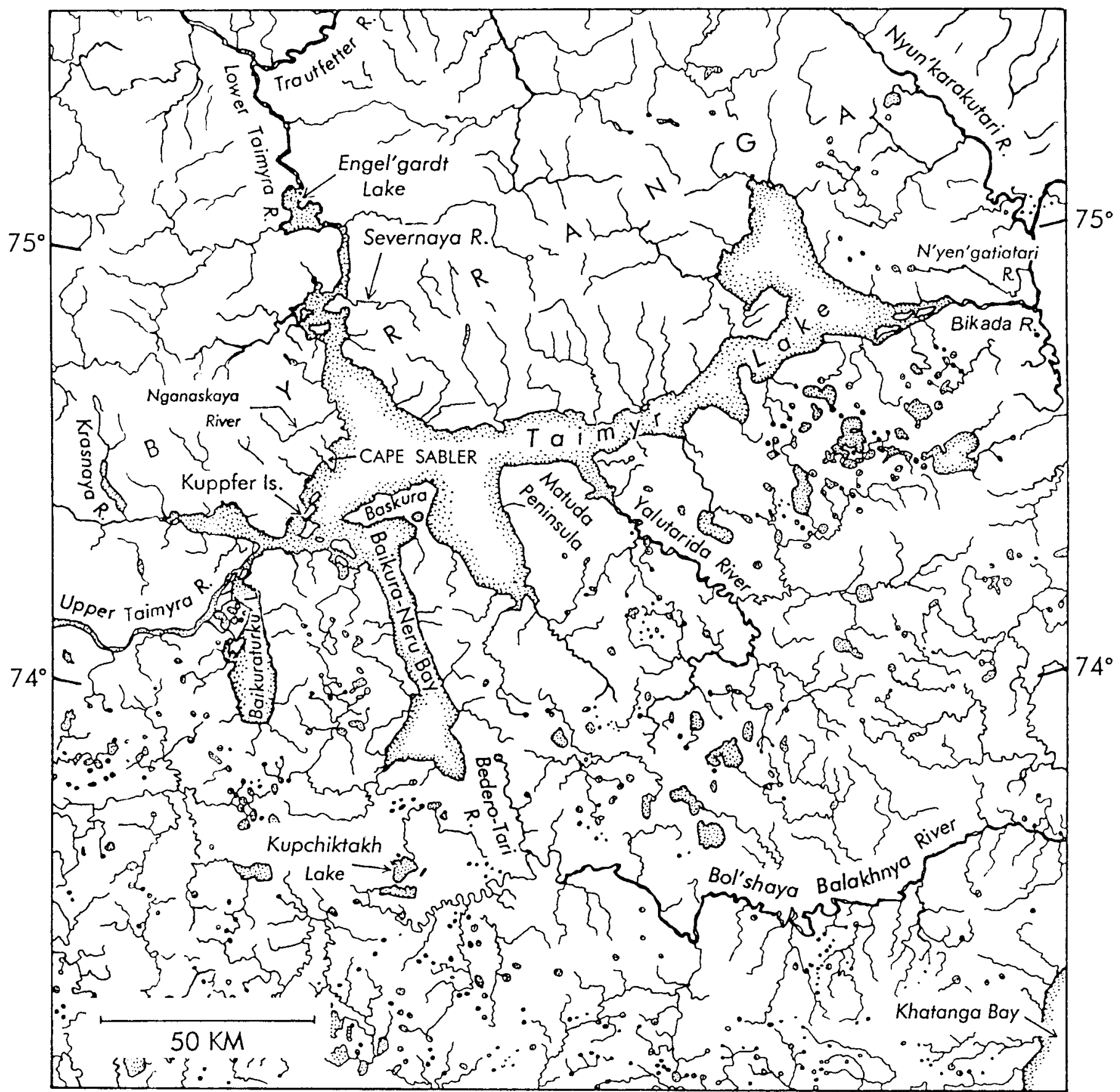

Figure 1(c).

Figure 1. The Asian high Arctic periphery: (a) North-central section of Russian Federation; (b) Taimyr Peninsula and adjacent regions; and (c) Lake Taimyr and environs. Maps identify localities and basins named in text and Tables 1-5.

Study area: Khatanga and Taimyra basins, Taimyr Peninsula

Historically, most fossil collecting activities in Taimyr have been conducted within the confines of the peninsula's two largest river basins (Figure 1(b),(c)), the Khatanga and the Taimyra (latter term used in preference to "Taimyr basin" to avoid confusion with peninsular name). The Khatanga, the major river system of the central part of the northern Siberian lowlands, arises from major tributaries (e.g., Kheta, Kotuy) that drain the north slopes of the Putorana plateau, and also receives major affluents from the south-east (Popygai) and the north (Bol'shaya Balakhnya). The Taimyra system is composed of two large rivers, the Upper (Verkhnyaya) Taimyra and Lower (Nizhnyaya) Taimyra. The former ends and the latter begins in the 
1022 R. D. E. MacPhee et al.

Table 1. AMS ${ }^{14}$ C ages, late Quaternary megafaunal mammals from eastern Taimyr Peninsula (Russian Federation)

\begin{tabular}{|c|c|c|c|}
\hline Lab Code $^{1}$ & Specimen & Provenance $^{2}$ & $\begin{array}{l}\text { Age }\left({ }^{14} \mathrm{C} \text { yr BP, }\right. \\
\left.\delta^{13} \mathrm{C} \text { corrected }\right)\end{array}$ \\
\hline \multicolumn{4}{|c|}{ Mammuthus primigenius } \\
\hline GrA-17350 & Mandible & Bikada R & $9920 \pm 60$ \\
\hline Beta- 148640 & Tusk & Gol'tsovaya $\mathrm{R}$ & $10,270 \pm 40$ \\
\hline Beta-148663 & Ulna & Arilakh L & $11,940 \pm 40$ \\
\hline Beta-148636 & Femur & Near Sopochnaya settlement & $13,560 \pm 40$ \\
\hline Beta-148642 & Femur & Sabler C & $15,390 \pm 50$ \\
\hline Beta-148646 & Molar & Bol'shaya Balakhnya R & $18,190 \pm 60$ \\
\hline GrA- $17347^{3,4}$ & Skull & Upper Taimyra $\mathrm{R}$, internal delta & $20,500 \pm 90$ \\
\hline Beta-148647 3,4 & Humerus & Upper Taimyra $\mathrm{R}$, internal delta & $20,620 \pm 70$ \\
\hline Beta-148633 & Mandible & Taimyr P & $20,800 \pm 70$ \\
\hline GrA-17604 & Calcaneus & Baskura P (Taimyr L) & $20,950 \pm 190$ \\
\hline Beta-148639 & Skull & Trautfetter R & $24,170 \pm 110$ \\
\hline Beta-148651 & Skull & Munchirdakh L & $24,250 \pm 110$ \\
\hline Beta-148634 & Thoracic vert. & Near Sopochnaya settlement & $25,800 \pm 130$ \\
\hline Beta-148665 & Humerus & Baskura P (Taimyr L) & $26,100 \pm 170$ \\
\hline Beta-148662 & Ulna & Taimyr $\mathrm{P}$ & $28,270 \pm 210$ \\
\hline Beta-148643 & Molar & Taimyr L, coast opposite Kupffer Is & $28,310 \pm 170$ \\
\hline Beta-148635 & Humerus & Talalakh L & $29,990 \pm 280$ \\
\hline Beta-148637 & Molar & Talalakh L & $30,890 \pm 290$ \\
\hline Beta-148644 ${ }^{3}$ & Skull & Bol'shaya Balakhnya $\mathrm{R}$ & $31,580 \pm 240$ \\
\hline Beta-148631 & Tibia & Baikuraturku L & $31,580 \pm 330$ \\
\hline Beta-148667 & Skull & Sabler C & $32,530 \pm 270$ \\
\hline Beta- $148650^{3,5}$ & Ulna & Novaya $\mathrm{R}$ & $32,600 \pm 280$ \\
\hline Beta-148632 & Tibia & Taimyr $\mathrm{P}$ & $32,750 \pm 280$ \\
\hline Beta-148641 & Femur & Arilakh L & $32,840 \pm 290$ \\
\hline Beta-148630 & Mandible & Arilakh L & $36,950 \pm 450$ \\
\hline Beta-148666 & Skull & Popygai R & $37,080 \pm 460$ \\
\hline Beta-148664 & Pelvis & Arilakh L & $39,050 \pm 580$ \\
\hline Beta-148638 & Mandible & Trautfetter R & $39,560 \pm 910$ \\
\hline Beta-148645 & Pelvis & Sabler C & $40,560 \pm 700$ \\
\hline Beta- $148648^{3,6}$ & Tibia & Arilakh L & $40,790 \pm 970$ \\
\hline GrA- $17439^{3,5}$ & Thoracic vert. & Novaya $\mathrm{R}$ & $41,580+1190 /-1040$ \\
\hline Beta- $148668^{3,6}$ & Humerus & Arilakh L & $43,160 \pm 1280$ \\
\hline GrA-17499 3,6 & Femur & Arilakh L & $43,500 \pm 1000$ \\
\hline Beta-148669 & Molar & Popygai R & $47,660 \pm 1650$ \\
\hline Beta- $148649^{3,6}$ & Femur & Arilakh L & $>49,210$ \\
\hline \multicolumn{4}{|l|}{ Ovibos moschatus } \\
\hline Beta-148653 & Skull & Sabler C & $15,800 \pm 50$ \\
\hline Beta-148628 & Horn sheath & Taimyr L, S of Sabler C & $18,370 \pm 70$ \\
\hline Beta-148627 & Atlas vert. & Sabler C & $19,310 \pm 80$ \\
\hline Beta-148654 & Skull & Bol'shaya Balakhnya R & $19,710 \pm 70$ \\
\hline GrA-17500 & Horn sheath & Taimyr L, coast opposite Kupffer Is & $20,770 \pm 180$ \\
\hline Beta-148629 & Skull & Yalutarida R delta, Matuda P & $21,190 \pm 90$ \\
\hline Beta- 148658 & Skull & Khatanga townsite & $21,330 \pm 70$ \\
\hline Beta- $148655^{3,7}$ & Skull & Popygai R & $21,500 \pm 100$ \\
\hline GrA- $17605^{3,7}$ & Skull & Popygai R & $22,530 \pm 220$ \\
\hline Beta-156194 & Metapodial & Taimyr L, coast opposite Kupffer Is & $22,370 \pm 80$ \\
\hline Beta-148652 & Metapodial & Taimyr L, coast opposite Kupffer Is & $22,610 \pm 100$ \\
\hline Beta-148657 & Femur & Upper Taimyra $\mathrm{R}$ & $24,660 \pm 110$ \\
\hline Beta-148656 & Skull & Sabler C & $27,440 \pm 150$ \\
\hline GrA-17349 & Skull & Sabler C & $32,540 \pm 210$ \\
\hline UtC-10156 & Skull & Bikada R & $36,700 \pm 700$ \\
\hline Beta-148626 & Skull & Sabler C & $42,680 \pm 1240$ \\
\hline \multicolumn{4}{|l|}{ Bison priscus } \\
\hline Beta-148623 & Hornsheath & Popygai R & $8860 \pm 40$ \\
\hline Beta-148624 & Metapodial & Sabler C & $39,760 \pm 870$ \\
\hline Beta- 148625 & Tibia & Talalakh L & $45,320 \pm 1740$ \\
\hline \multicolumn{4}{|l|}{ Equus caballus } \\
\hline Beta-148659 & Radius-ulna & Taimyr L & $17,950 \pm 60$ \\
\hline GrA-17351 & Skull & Arilakh L & $18,090 \pm 80$ \\
\hline Beta-148660 & Skull & Sabler C & $24,690 \pm 110$ \\
\hline Beta-148622 & Tibia & Talalakh L & $36,770 \pm 610$ \\
\hline
\end{tabular}


Table 1. Continued

\begin{tabular}{|c|c|c|c|}
\hline Lab Code ${ }^{1}$ & Specimen & Provenance $^{2}$ & $\begin{array}{l}\text { Age }\left({ }^{14} \mathrm{C} \text { yr вP, }\right. \\
\left.\delta^{13} \mathrm{C} \text { corrected }\right)\end{array}$ \\
\hline \multicolumn{4}{|l|}{ Alces alces } \\
\hline Beta-148621 & Frontal & Near Sopochnaya settlement & $4050 \pm 40$ \\
\hline GrA-17346 & Antler & Novaya R, Ari-Mas & $47,900+1000 /-9000$ \\
\hline \multicolumn{4}{|l|}{ Canis lupus } \\
\hline Beta- $148620^{3}$ & Skull & Sabler C & $16,310 \pm 50$ \\
\hline GrA- $17432^{3}$ & Skull & Sabler C & $16,670 \pm 70$ \\
\hline \multicolumn{4}{|c|}{ Rangifer tarandus } \\
\hline GrA-17497a ${ }^{3}$ & Lower molar & Taimyr L & $8700 \pm 45$ \\
\hline GrA-17497b & Mandible & Taimyr L & $8710 \pm 60$ \\
\hline \multicolumn{4}{|c|}{$\begin{array}{l}{ }^{1} \text { GrA, Groningen AMS, Center for Isotope Research (The Netherlands); Beta, Beta Analytic, Inc. (Florida, } \\
\text { U.S.A.). Ages are cited as } \delta^{13} \mathrm{C} \text { corrected mean age } \pm 1 \text { sigma }(\sigma) \text {. } \\
{ }^{2} \text { Geographical abbreviations: B, bay; C, cape; Is, island(s); L, lake; NNE, north northeast; P, peninsula; R, river; } \\
\text { S, south. } \\
{ }^{3} \text { Replicate date for this specimen/individual; see Table } 3 \text { for weighted average. } \\
{ }^{4} \text { Hook mammoth. } \\
{ }^{5} \text { Markel mammoth. }\end{array}$} \\
\hline
\end{tabular}

western end of the large but shallow Lake Taimyr, situated in the lowest part of the Taimyra basin. The Lower Taimyra, which drains northward to the Kara Sea, has several tributaries of proven paleontological importance (e.g., Shrenk, Mamonta). A third watershed, the Bikada, drains into the lake from the east. Tributaries of the Bikada include the Nyun'karakutari and N'yen'gatiatari, both of which have yielded important fossils.

Other basins in Taimyr (e.g., Leningradskaya, Pyasina) have been less intensively collected but are undoubtedly worth additional prospecting (cf. Sulerzhitsky \& Romanenko, 1999). This point also applies to peninsular coastlines and the Severnaya Zemlya islands to the north of Taimyr proper. For completeness we make brief reference to the few dates on fossils from these other areas and include them in certain analyses.

Lake Taimyr is situated on the southern margin of the Byrranga mountains (max. elev., $1146 \mathrm{~m}$ ), which extend in a narrow arc across the peninsula from southwest to northeast and provide the area's only substantial relief. North of the lake, the landscape is generally rugged and hilly. To the south, it merges with the nearly featureless northern Siberian lowland belt. As a result, the divide between the Khatanga and Taimyra basins is very low $(<50 \mathrm{~m}$ asl). According to Möller et al. (1999), on at least one occasion during the late Quaternary the water level in Lake Taimyr rose far above its current elevation ( $5 \mathrm{~m}$ asl). Overflow from the lake would have drained into the Khatanga basin via the headwaters of the Bol'shaya Balakhnya, with the result that large areas of the lowlands on either side of the river would have been shallowly submerged for a time. Spillover along the course of the Upper Taimyra may have also affected the western part of the Taimyr Peninsula (P. Möller, pers. commun.).

The $60-\mathrm{km}$ wide Vil'kitskogo Strait that presently separates the Severnaya Zemlya islands from Cape Chelyuskin reaches depths between 100 and $200 \mathrm{~m}$. Whether or not the islands and mainland were actually continuous during the last glaciation, it is probable that megafauna could have crossed (and re-crossed) over sea ice at any time when conditions permitted. Thus it is reasonable to link the faunal history of Severnaya Zemlya with that of the mainland. The current dating record (four dates, Mammuthus only) is not dense enough to make useful inferences about the length of megafaunal tenure on these islands, although it is sufficient to establish that mammoths survived on the middle island, Oktyabr'skoy Revolyutsii, until nearly the end of the Pleistocene (Sulerzhitsky \& Romanenko, 1999).

\section{Taphonomic considerations}

Although the discovery of individual megafaunal carcasses in northern Asia tends to generate considerable interest, such discoveries are chiefly noteworthy because they occur so rarely (see Vereshchagin \& Tikhonov, 1999; Mol et al., 2001a,b). Indeed, although megafaunal bone is a common sight in Taimyr, it is rather unusual to encounter skeletons or even associated elements. For example, the beach along the east side of Cape Sabler, Lake Taimyr (Figure 1), is acknowledged to be one of the best collecting areas on the peninsula. From simple positional considerations it is obvious that bones which end up on the cape's beach 
1024 R. D. E. MacPhee et al.

Table 2. Conventional ${ }^{14} \mathrm{C}$ ages, late Quaternary megafaunal mammals from eastern Taimyr Peninsula (Russian Federation

\begin{tabular}{|c|c|c|c|}
\hline Lab Code $^{1}$ & Element & Provenance & $\begin{array}{c}\text { Age }\left({ }^{14} \mathrm{C} \text { yr BP, }\right. \\
\left.\text { not } \delta^{13} \mathrm{C} \text { corrected }\right)\end{array}$ \\
\hline \multicolumn{4}{|c|}{ Mammuthus primigenius } \\
\hline GIN-10508 & Tusk & $\begin{array}{l}\text { N'yen'yatiatari R } \\
\left(74^{\circ} 50 \cdot 0^{\prime} \mathrm{N}, 106^{\circ} 10 \cdot 0^{\prime} \mathrm{E}\right)\end{array}$ & $10,070 \pm 60$ \\
\hline GIN-11138a & Molar & $\begin{array}{l}\text { Kupchiktakh L } \\
\left(73^{\circ} 35 \cdot 9^{\prime} \mathrm{N}, 101^{\circ} 07 \cdot 8^{\prime} \mathrm{E}\right)\end{array}$ & $10,200 \pm 40$ \\
\hline GIN-10507 & Tibia & $\begin{array}{l}\text { Nyun'karakutari R } \\
\left(75^{\circ} 21 \cdot 0^{\prime} \mathrm{N}, 105^{\circ} 30 \cdot 0^{\prime} \mathrm{E}\right)\end{array}$ & $10,270 \pm 120$ \\
\hline GIN-10552 & Molar & $\begin{array}{l}\text { Krasnaya R } \\
\left(74^{\circ} 34 \cdot 0^{\prime} \mathrm{N}, 98^{\circ} 30 \cdot 0^{\prime} \mathrm{E}\right)\end{array}$ & $10,790 \pm 100$ \\
\hline GIN-10506 & $\begin{array}{l}\text { Bone } \\
\text { (unspecified) }\end{array}$ & $\begin{array}{l}\text { Bikada R } \\
\left(74^{\circ} 50 \cdot 0^{\prime} \mathrm{N}, 106^{\circ} 00 \cdot 0^{\prime} \mathrm{E}\right)\end{array}$ & $12,050 \pm 150$ \\
\hline GIN-11127 & Tusk & $\begin{array}{l}\text { Bol'shaya Balakhnaya R } \\
\left(73^{\circ} 35^{\circ} 7^{\prime} \mathrm{N}, 100^{\circ} 33^{\prime} 4^{\prime} \mathrm{E}\right)\end{array}$ & $26,200 \pm 150$ \\
\hline GIN-11130a ${ }^{2}$ & Skull & $\begin{array}{l}\text { Bol'shaya Balakhnaya R } \\
\left(73^{\circ} 36 \cdot 2^{\prime} \mathrm{N}, 100^{\circ} 29^{\cdot} 7^{\prime} \mathrm{E}\right)\end{array}$ & $30,850 \pm 200$ \\
\hline GIN-11137 & Molar & $\begin{array}{l}\text { Kupchiktakh L } \\
\left(73^{\circ} 35 \cdot 9^{\prime} \mathrm{N}, 101^{\circ} 07 \cdot 8^{\prime} \mathrm{E}\right)\end{array}$ & $32,200 \pm 800$ \\
\hline GIN-11128 & Rib & $\begin{array}{l}\text { Bol'shaya Balakhnaya R } \\
\left(73^{\circ} 32 \cdot 1^{\prime} \mathrm{N}, 100^{\circ} 29 \cdot 2^{\prime} \mathrm{E}\right)\end{array}$ & $>38,600$ \\
\hline GIN-11127a & Tusk & $\begin{array}{l}\text { Bol'shaya Balakhnaya R } \\
\left(73^{\circ} 35 \cdot 7^{\prime} \mathrm{N}, 100^{\circ} 33 \cdot 4^{\prime} \mathrm{E}\right)\end{array}$ & $39,300 \pm 600$ \\
\hline GIN-11134 & Sacrum & $\begin{array}{l}\text { Bol'shaya Balakhnaya R } \\
\left(73^{\circ} 32 \cdot 1^{\prime} \mathrm{N}, 100^{\circ} 29 \cdot 2^{\prime} \mathrm{E}\right)\end{array}$ & $40,200 \pm 600$ \\
\hline \multicolumn{4}{|c|}{ Ovibos moschatus } \\
\hline GIN-25529 & Skull & $\begin{array}{l}\text { Pronchishchev B } \\
\text { (no specific coordinates) }\end{array}$ & $2900 \pm 60$ \\
\hline GIN-11130 & Cervical vertebra & $\begin{array}{l}\text { Bol'shaya Balakhnaya R } \\
\left(73^{\circ} 36 \cdot 2^{\prime} \mathrm{N}, 100^{\circ} 29 \cdot 8^{\prime} \mathrm{E}\right)\end{array}$ & $>39,000$ \\
\hline \multicolumn{4}{|l|}{ Equus caballus } \\
\hline GIN-10509 & Maxilla & $\begin{array}{l}\text { Nyun'karakutari R } \\
\left(75^{\circ} 18^{\prime} \mathrm{N}, 105^{\circ} 45^{\prime} \mathrm{E}\right)\end{array}$ & $9010 \pm 140$ \\
\hline GIN-11133 & Femur & $\begin{array}{l}\text { Bol'shaya Balakhnaya R } \\
\left(73^{\circ} 32 \cdot 1^{\prime} \mathrm{N}, 100^{\circ} 29 \cdot 2^{\prime} \mathrm{E}\right)\end{array}$ & $17,000 \pm 150$ \\
\hline GIN-11132 & Scapula & $\begin{array}{l}\text { Bol'shaya Balakhnaya R } \\
\left(73^{\circ} 31 \cdot 6^{\prime} \mathrm{N}, 100^{\circ} 29 \cdot 6^{\prime} \mathrm{E}\right)\end{array}$ & $23,900 \pm 400$ \\
\hline GIN-11129 & Tibia & $\begin{array}{l}\text { Bol'shaya Balakhnaya R } \\
\left(73^{\circ} 36^{\circ} 7^{\prime} \mathrm{N}, 100^{\circ} 24 \cdot 8^{\prime} \mathrm{E}\right)\end{array}$ & $32,800 \pm 900$ \\
\hline GIN-11136 & Bone & $\begin{array}{l}\text { Kupchiktakh L } \\
\left(73^{\circ} 36 \cdot 4^{\prime} \mathrm{N}, 100^{\circ} 08 \cdot 9^{\prime} \mathrm{E}\right)\end{array}$ & $>30,000$ \\
\hline GIN-11135 & Femur & $\begin{array}{l}\text { Kupchiktakh L } \\
\left(73^{\circ} 36 \cdot 4^{\prime} \mathrm{N}, 101^{\circ} 08 \cdot 9^{\prime} \mathrm{E}\right)\end{array}$ & $>40,400$ \\
\hline \multicolumn{4}{|c|}{ Rangifer tarandus } \\
\hline GIN-11131 & Bone & $\begin{array}{l}\text { Bol'shaya Balakhnaya R } \\
\left(73^{\circ} 36 \cdot 2^{\prime} \mathrm{N}, 100^{\circ} 29 \cdot 8^{\prime} \mathrm{E}\right)\end{array}$ & $20,250 \pm 90$ \\
\hline GIN-11138 & Antler & $\begin{array}{l}\text { Bol'shaya Balakhnaya R } \\
\left(73^{\circ} 35 \cdot 0^{\prime} \mathrm{N}, 100^{\circ} 04 \cdot 5^{\prime} \mathrm{E}\right)\end{array}$ & $<38,600$ \\
\hline
\end{tabular}

${ }^{1}$ GIN, Geological Institute, Russian Academy of Sciences (Russia). For other abbreviations, see Table 1. Ages are cited as measured (raw) mean date $\pm 1 \sigma$.

${ }^{2}$ Cf. B-148644, Table 1 (same specimen).

must be eroding out of the cliff face that towers above it, which is composed of unconsolidated silts, peats, sands, and gravels at base (for a detailed description, see Möller et al., 1999). However, it is quite uncommon to see bones actually in situ in the cliff face before they erode out, and articulated elements are almost never encountered as such. These points suggest that, for the most part, (a) the bones contained in the Cape Sabler deposits probably occur as isolated elements, not as articulated skeletons, and that (b) they do not regularly occur in concentrations, but are widely dispersed in the sediments. Earlier bouts of collecting activity cannot explain the lack of numerous associated remains at present, as new material is presumably eroding out all 
Table 3. Replicate age estimates and weighted average ages for selected specimens noted in Tables 1 and $2^{1}$

\begin{tabular}{|c|c|c|c|c|}
\hline Specimen & Lab Code & Element & $\begin{array}{c}\text { Age } \\
\left({ }^{14} \mathrm{C} \text { yr BP }\right)^{2}\end{array}$ & $\begin{array}{l}\text { Weighted } \\
\text { Average } \\
\left({ }^{14} \mathrm{C} \text { yr } \mathrm{BP}\right)\end{array}$ \\
\hline \multirow[t]{3}{*}{ Jarkov mammoth } & UtC-8137 & Bone & $19,920 \pm 130$ & \multirow[t]{3}{*}{$20,200 \pm 80$} \\
\hline & UtC-8138 & Hair & $20,380 \pm 140$ & \\
\hline & UtC-8139 & Skin & $20,390 \pm 160$ & \\
\hline \multirow[t]{2}{*}{ Hook mammoth } & GrA-17347 & Skull & $20,500 \pm 90$ & \multirow{2}{*}{$20,560 \pm 60$} \\
\hline & Beta-148647 & Humerus & $20,620 \pm 70$ & \\
\hline \multirow[t]{2}{*}{ Markel mammoth ${ }^{3}$} & GrA-17439 & Vertebra & $41,580+1190 /-1040$ & \multirow[t]{2}{*}{$32,950 \pm 250$} \\
\hline & Beta- 148650 & Ulna & $32,600 \pm 280$ & \\
\hline \multirow[t]{3}{*}{ Pilot's Site mammoth ${ }^{4}$} & Beta-148648 & Tibia & $40,790 \pm 970$ & \multirow[t]{3}{*}{$42,420 \pm 500$} \\
\hline & Beta-148668 & Humerus & $43,160 \pm 1280$ & \\
\hline & GrA-17499 & Femur & $43,500 \pm 1000$ & \\
\hline \multirow[t]{2}{*}{ Bol'shaya Balakhnya mammoth } & Beta-148644 & Skull & $31,520 \pm 240$ & \multirow[t]{2}{*}{$31,230 \pm 140$} \\
\hline & GIN-11130a & & $30,850 \pm 200$ & \\
\hline \multirow[t]{2}{*}{ Popigay muskox } & Beta- 148655 & Skull & $21,500 \pm 100$ & \multirow[t]{2}{*}{$21,710 \pm 90$} \\
\hline & GrA-17605 & & $22,530 \pm 200$ & \\
\hline \multirow[t]{2}{*}{ Lake Taimyr wolf } & Beta- 148620 & Skull & $16,310 \pm 50$ & \multirow[t]{2}{*}{$16,430 \pm 40$} \\
\hline & GrA-17432 & & $16,670 \pm 70$ & \\
\hline \multirow[t]{2}{*}{ Lake Taimyr reindeer } & GrA-17497a & Molar & $8700 \pm 45$ & \multirow[t]{2}{*}{$8700 \pm 40$} \\
\hline & GrA-17497b & Mandible & $8710 \pm 60$ & \\
\hline
\end{tabular}

${ }^{1}$ Weighted average method of Long \& Rippeteau (1974).

${ }^{2}$ Assays are $\delta^{13} \mathrm{C}$ corrected except in case of estimates for Bol'shaya Balakhnya skull (Beta-148644 not corrected in order to accord with GIN-11130a, for which there is no $\delta^{13} \mathrm{C}$ estimate). Weighted averages for this specimen is therefore probably $30-70 \mathrm{yr}$ too young.

${ }^{3}$ Dates for Markel mammoth are not compatible and weighted mean is not judged to be a reliable indicator of age. At least one additional date is needed to resolve problem.

${ }^{4} \mathrm{Based}$ on the three finite dates listed in Table 1. The fourth date, which is nonfinite $(>49,180$, Beta-148649), is significantly older and was not utilized.

the time. We suggest that these observations apply generally to the taphonomy of Taimyr, particularly to the more rugged parts of the peninsula situated north of the lake.

Nevertheless, this situation is somewhat surprising. Among other factors, low mean temperature and apparent scarcity of large meat-eaters in Taimyr during the past several tens of thousands of years should have favoured slow decomposition and even slower derangement of megafaunal skeletal associations. For the vast majority of specimens, human transport is unlikely because there is no evidence that people had reached Taimyr or adjacent regions of northernmost Siberia until the very end of the Pleistocene or early Holocene (Kuzmin \& Tankersley, 1996; Orlova et al., 2000; Pitul'ko, 2001). Great concentrations of specimens, like those at Berelekh (Vereschagin \& Baryshnikov, 1984), are never encountered in Taimyr. Moreover, no butchering marks were seen on any of the mammoth material collected by the CME, nor have any such alterations been reported previously. Accordingly, by default ice and water must be considered the primary agents of bone dispersal along the high Arctic periphery. Carcasses can be torn apart by moving ice shearing off exposed limbs or other bodily parts, especially during spring breakup when carcasses may only be partly frozen to the ground. This must be why intact limbs, sometimes with soft tissues still attached, can occur in isolation, without any other portions of the body in the vicinity. Ice can also cause push fractures, breaking up even the largest and thickest elements like mammoth femora and humeri.

Since most fossil finds are made in river valleys, it is logical to think that events like spring breakup must be responsible for moving elements to and fro. But even if the majority of fossil specimens have been subject to repeated redeposition, many have just as clearly not. Indeed, the exquisite condition of many specimens indicates quite the opposite. For example, mammoth skulls with intact molars, tusks, and nasal turbinals are occasionally found at surface without any bones belonging to the same skeleton nearby (Figure 3). This presumably indicates that either the skull or, alternatively, all the rest of the skeleton, had to have been moved at least once - but perhaps only once, which is the important point. Although an intact mammoth skull with tusks may weigh $100-150 \mathrm{~kg}$ or more, extensive pneumatization would provide some buoyancy (cf. Shipman, 1981; Todd \& Frison, 1986). One might infer that only large volumes of water, moving at high velocity, would be able to move such an object a significant distance, but without proper taphonomic experimentation this can only be considered an inference.

Tusks provide a parallel case. A tusk of a large male woolly mammoth can weigh as much as $80 \mathrm{~kg}$, at least in a water-logged state (D. Mol, pers. obs.). Of the 160 tusks in varying states of completeness collected by 
1026 R. D. E. MacPhee et al.
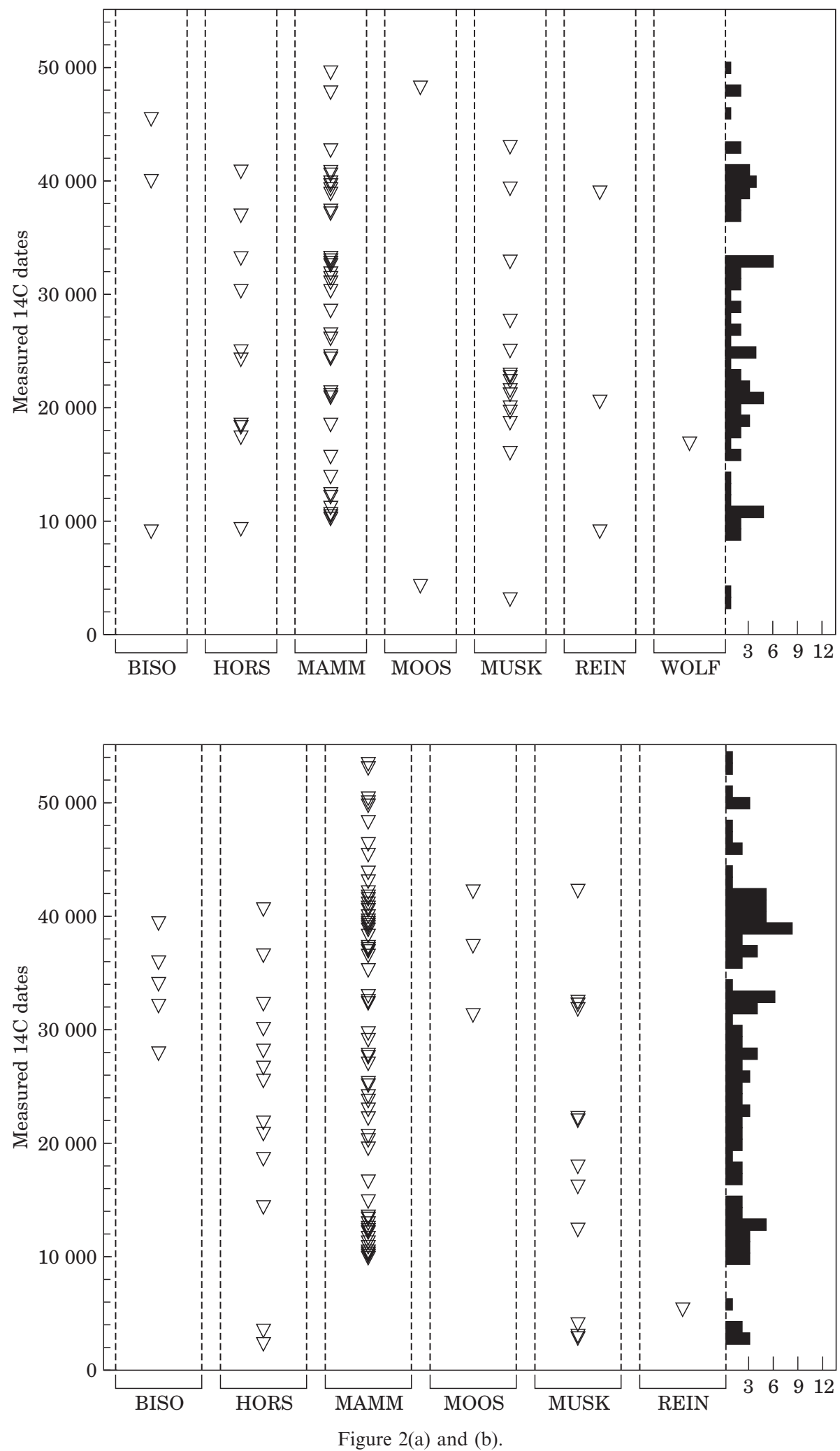


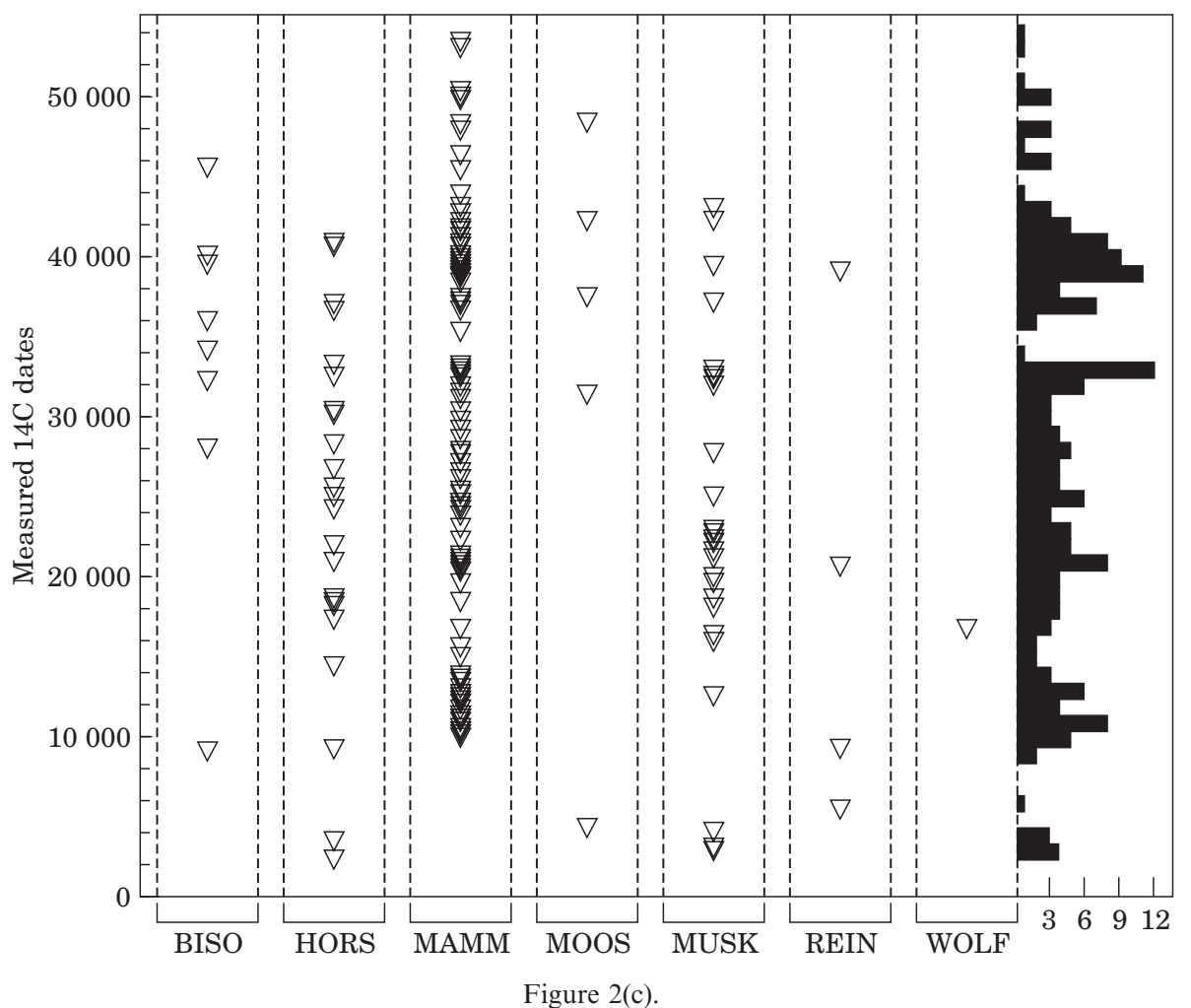

Figure 2. Scattergram/histogram presentations depicting current radiocarbon dating information on late Quaternary mammalian taxa from Taimyr Peninsula, Russian Federation: (a) 75 AMS and conventional dates reported in this paper (see Tables 1-3); (b) 112 previously-published dates (various sources); (c) combination of datasets in (a) and (b). "Radiocarbon dates" are means of individual radiocarbon assays, whether AMS or conventional; variates are grouped in intervals of 1000 years. "Previously published" dates are ones selected primarily from lists published by Sulerzhitsky (1995), Sulerzhitsky \& Romanenko (1997, 1999), and Vasil'chuk et al. (1997). Key: BISO, Bison priscus; HORS, Equus caballus; MAMM, Mammuthus primigenius; MOOS, Alces alces; MUSK, Ovibos moschatus; REIN, Rangifer tarandus; WOLF, Canis lupus.

For Beta Analytic AMS dates only $(N=50)$, grand mean=27,390 yr BP (S.D. $=10,780)$; for previously published dates only, grand mean $=28,420 \mathrm{yr}$ BP (s.D. $=12,925)$. Differences in distributions of variates in the two data sets are not significant at the $0 \cdot 05$ level as judged by both parametric and non-parametric tests (unpaired $t$ test, $P=0 \cdot 47$; Kolmogorov-Smirnov statistic, $P=0 \cdot 42$; Mann-Whitney statistic, $P=0 \cdot 36$ ), nor was Hartley's $F$-test for homogeneity of variances comparing Beta Analytic and previously reported GIN subsets (variance ratio $F=1 \cdot 3818$.

Although dates are scattered over the whole period accessible to radiocarbon dating, some intervals appear to be much more heavily sampled than others (concentrations). There are also some apparent gaps (rarefactions) for which there are few or no dated specimens. See text for discussion.

CME personnel prior to August, 2001, there are only four obvious pairs (i.e., paired tusks belonging to a single individual). Obviously, tusks, like skulls and long bones, do move.

\section{Methods}

\section{Collecting methods}

Specimen collection was performed by CME personnel as well as by hired collectors who worked in designated drainages in several parts of eastern Taimyr and the Khatanga watershed. Most collected material was brought to the central processing station at Cape Sabler for eventual packing and removal by helicopter to the expedition's cold storage "ice cave" in Khatanga
(Mol et al., 2001b). A number of other specimens, collected years earlier by other hands, have also been deposited in the Khatanga CME collection.

Fossil hunting in eastern Taimyr is generally conducted along lake margins and river banks, and our collecting effort was no exception. This bias simply recognizes the fact that bones are exposed in riparian settings much more frequently than they are on the tundra. It is also considerably easier to see and collect fossils in areas that lack any vegetation whatsoever. Finally, in eastern Taimyr permafrost begins within a meter of the surface; excavation is therefore indicated only in the case of unusual finds or concentrations of bones.

For most specimens, the only provenance information is the drainage in which the find was made. However, as an experiment (cf. Table 2), some local 


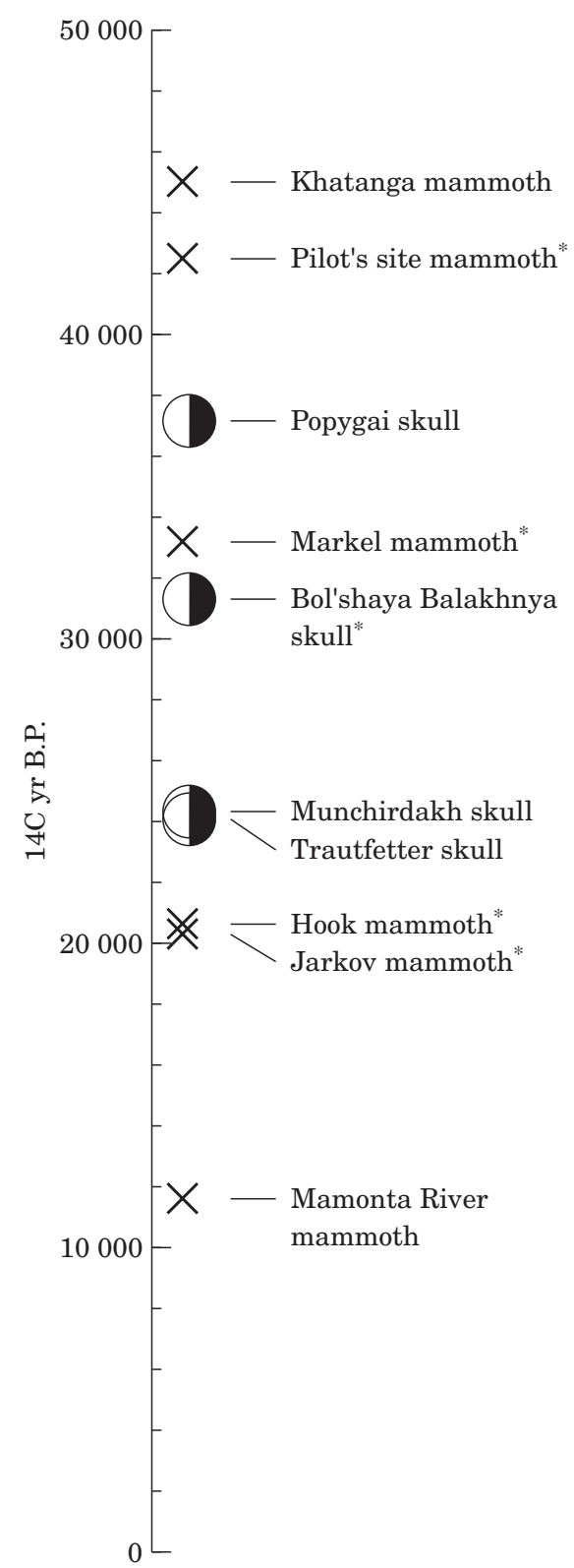

Figure 3. Age distribution of substantially complete skeletons (crosses) and isolated skulls (half-filled circles) of Mammuthus primigenius having known provenances in Taimyr. Some of the singleton skulls may have been associated with postcranials that were not retrieved (or recognized as such) at the time of discovery. Weighted average ages are given for specimens marked by asterisks (see Table 3). For details, see text. Skeletons: Khatanga, $45,000 \pm 200 \mathrm{yr}$ BP (MAG-369); Pilot's Site, 42,420 $\pm 500 \mathrm{yr}$ BP (Table 3); Markel, $32,950 \pm 250 \mathrm{yr}$ BP (Table 3); Hook, 20,560 $\pm 60 \mathrm{yr}$ BP (Table 3); Jarkov, 20,200 \pm 80 yr BP (Table 3); Mamonta River (Mammuthus primigenius neotype), $11,450 \pm 250 \mathrm{yr}$ BP (T-297). Skulls: Trautfetter, $24,170 \pm 110 \mathrm{yr}$ BP (B-148639); Munchirdakh, 24,250 $\pm 110 \mathrm{yr}$ BP (B-148651); Bol'shaya Balakhnya, 31,230 \pm 140 yr BP (see Table 3); Popygai, $37,080 \pm 460 \mathrm{yr}$ BP (B-148666). For isotope lab abbreviations see Table 4.

collectors were provided with GPS units to record exact locations (latitude and longitude; altitude was not recorded). Although it might be argued that such precision is pointless for surface-deposited specimens, in fact it can be very helpful in determining the proximity of specimens to one another, or which parts of a drainage have been well collected.

\section{Specimen selection}

The majority of the dates that we report here are derived from teeth and long-bone compactum. Specimens for dating were selected according to overall quality of preservation, taxonomic representativeness, and likelihood of DNA recovery. Intact long bones were preferred over other elements because we have had notable success in extracting DNA from marrow tissues preserved in medullary cavities (Greenwood et al., 2001). (Results of our ancient DNA investigations will be reported elsewhere.)

Another reason for concentrating on well preserved material was our belief that such specimens would, on the whole, turn out to be relatively recent and therefore have a bearing on refining estimates of "last" occurrences of megafaunal species (MacPhee \& Marx, 1997; Martin \& Steadman, 1999). Our results (Tables 1, 2) show that this belief was misplaced. Although there is of course some correlation between excellence of preservation and relative recency, on the tundra the correlation is not high: generally speaking, appearance is not a good index of antiquity, and well preserved material can be of any age. For most of the late Quaternary, Taimyr's extremely cold winters, combined with short, cool summers and little annual precipitation, have insured that conditions optimal for the preservation of bone have prevailed there for at least the last 50,000 years (and no doubt much longer).

\section{Sampling methods}

After photographic recording, specimens selected for dating or molecular studies were sampled (either by coring out material with an electric drill, or detaching pieces with pliers). Samples were immediately placed in separate containers (cone tubes or plastic bags, depending on size), labelled, and stored for later processing. Marrow, if present, was scooped into cone tubes, labelled, and stored at cool temperatures $\left(\sim 5-10^{\circ} \mathrm{C}\right)$ until processing.

Coring was accomplished with diamond-edged "hole-saw" drill bits, $\sim 1$ and $2 \mathrm{~cm}$ in diameter (available from Triatic Inc., 22 Grassmere Ave., West Hartford, CT 06110). The bits worked well on small, relatively thin-walled elements such as muskox cannon bones. However, when drilling very thick material (e.g., mammoth long-bone compactum, muskox basicrania), a continuous water drip was necessary in order to prevent undue bit wear. Drill bits were washed in water after each sampling procedure, but it was usually difficult to remove all adherent material from the 
diamond edge. Small, portable ultrasound baths are recommended for work of this kind in future.

\section{Dating considerations}

Although chronometric records based on radiocarbon dating are of central importance to late Quaternary paleontology, it is necessary to keep in mind their limitations (van der Plicht, 1998, 2000). The INTCAL98 calibration curve (Stuiver et al., 1998), the current international standard, is based on several sources. The curve's backbone is provided by tree-ring chronology, which currently yields a continuous record extending back to $10,280 \mathrm{cal}$ yr BP. To this is added a separate, floating chronology, at present based only on German pine tree data, that extends the record back to 11,860 cal yr BP with an acknowledged probable uncertainty of $\pm 10 \mathrm{cal} \mathrm{yr}$ (Kromer \& Spurk, 1998). This interval embraces almost all of the period of greatest interest here. Corals with pairwise dates $\left({ }^{14} \mathrm{C}\right.$ and U-series) provide a third source of calibration and extend the INTCAL98 curve back to $15,585 \mathrm{cal}$ yr BP. However U-series dating is not tree-ring counting, and is therefore not "absolute". Further, because of marine reservoir effects, a factor of 400-500 cal yr must be used to "correct" dates based on coral. Beyond $15,585 \mathrm{cal}$ yr BP there are isolated pair-dated coral datapoints that extend the pertinent record to $\sim 40,000$ cal yr BP. Other cross-checking methods, including varves, are being tested and will no doubt lead to improvements and extensions (see van der Plicht (2000) and related papers published in the journal Radiocarbon, vol. 42(3)).

The shape of the calibration curve, which is empirical, is ultimately controlled by secular variation in the amount of atmospheric ${ }^{14} \mathrm{C}\left(\Delta^{14} \mathrm{C}\right)$. During the last 50,000 years, flux in $\Delta^{14} \mathrm{C}$ has been substantial. During the latest Pleistocene and Holocene the trend has been fairly regularly downward, toward lower atmospheric ${ }^{14} \mathrm{C}$ content. Within this interval, $\Delta{ }^{14} \mathrm{C}$ is now well understood (van der Plicht, 1998, 2000). Much more problematic are the massive excursions that punctuate earlier parts of the radiocarbon record, particularly because different methodologies used to investigate flux do not produce the same results. Thus Beck et al. (2001) recently reported the existence of markedly fluctuating $\Delta{ }^{14} \mathrm{C}$ values between 45,000 and $33,000 \mathrm{cal}$ yr BP, amounting at times to more than double the modern atmospheric ${ }^{14} \mathrm{C} /{ }^{12} \mathrm{C}$ ratio. However, this peak, which is based on stalagmite data, is not replicated in the Lake Suigetsu varve record published by Kitagawa \& van der Plicht (1998). Conversely, a peak recorded at $31,000 \mathrm{cal} \mathrm{yr} \mathrm{BP}$ in the varve record is not obvious in the stalagmite data (van der Plicht, 2000, in prep.). The meaning of these huge excursions in $\Delta{ }^{14} \mathrm{C}$ is likely to remain controversial (Yokoyama et al., 2000): at present, they cannot be accounted for by reference to any plausible level of change in the solar and terrestrial magnetic fields.
A final point concerns the comparative reliability of dates based on bone and other hard tissues. Although the propensity of dense connective tissues to uptake contaminants in the form of allochthonous carbon is certainly a consideration, in high-latitude, open-air terrestrial contexts like the Taimyr Peninsula, it is unlikely to be a major concern. In such contexts all processes leading to the release of stored carbon, such as mechanical or chemical erosion of sediments, production of $\mathrm{CO}_{2}$ by plants, or deposition via meteoric water, are relatively muted and slow. In the absence of carbonate rocks (outcropping rocks on the Taimyr are mostly Devonian shales), substantial reservoir effects are not likely.

\section{Results}

This section provides taxon-by-taxon assessment of results in comparison to previous chronometric studies. Radiometric assays are provided in Table 1 (AMS dates) and Table 2 (conventional scintillation dates); weighted averages for replicate datings of the same specimen or individual are given in Table 3. Statistical statements are based primarily on a database of 188 radiocarbon dates on megafaunal skeletal elements from Taimyr, collated from the literature and this paper. (Database available from senior author on request.) The software package Statview 5.0.1 (SAS Institute, Cary, North Carolina), PowerPC version, was used for all statistical tests. Replicates are omitted from computations and tallies unless otherwise indicated.

All radiocarbon dates are cited in radiocarbon years Before Present ("1950"), or "yr BP" AMS dates listed in Table 1 have been corrected for carbon isotope fractionation $\left(\delta^{13} \mathrm{C}\right)$; dates listed in Table 2 are uncorrected, as are the raw dates under the "Age" column in Table 4. Although it is certainly appropriate to distinguish between corrected and uncorrected dates when possible, in general the effect of $\delta^{13} \mathrm{C}$ on date computation is negligible for bones of terrestrial mammalian herbivores.

Many late Quaternary Asian megafaunal taxa are seriously oversplit. In general, we have tried to utilize the most widely accepted names and species concepts for the taxa of interest here. Reconstructed range maps for various parts of the Pleistocene for the taxa of interest here may be found in Kahlke's (1999) monograph.

\section{Woolly mammoth}

Current record and new results. The new radiocarbon dates $(N=46)$ for $M$. primigenius, including replicates, range from $>49,180$ to $9920 \pm 60 \mathrm{yr}$ BP (Tables 1-3). Despite selection bias toward putatively young material, $30(65 \%)$ of the samples (excluding replicates) proved to be older than 20,000 yr BP. Currently, the youngest date for $M$. primigenius in Taimyr 
is $9670 \pm 60 \mathrm{yr} \quad$ BP (GIN-1828; Sulerzhitsky \& Romanenko, 1997), for a tusk from the Lower Taimyra basin. At $2 \sigma$ this date virtually overlaps our youngest date (GrA-17350), which raises the possibility that we have sampled the same (presumably terminal) population of woolly mammoths. It is noteworthy that at least a dozen dates $<11,000 \mathrm{yr}$ BP are now recorded for Taimyr mammoth specimens (Figure 2(c)). We also take this opportunity to formally publish a weighted average date for the Jarkov mammoth (Table 3).

Evaluation. Because mammoths have long been a favourite subject for radiocarbon dating in northern Asia, the new dates by themselves add little that is novel. However, it seems reasonable to infer, on the basis of what is now a rather substantial dating sample (c. 130 dates for Taimyr mammoths, including replicates), that Mammuthus primigenius was either exceedingly rare or absent in Taimyr by $9500 \mathrm{yr}$ BP. Further treatment of the implications of this climacteric are reserved for a later section (see Discussion).

Of quite separate significance are dates for associated skeletal specimens of mammoths. CME personnel have so far collected or identified four partial skeletons of Mammuthus primigenius in eastern Taimyr. These include the well known Jarkov specimen and three others, dubbed the "Hook," "Markel" and "Pilot's Site" mammoths (Table 3). There is also a fifth collection of extremely well preserved bones (femur, humerus, and two pelves), recovered from an unspecified place on Cape Sabler many years ago, that are of comparable size, condition, and coloration. Dubbed the "White" mammoth, these remains were thought to constitute a single animal. However, dates on the femur $(15,390 \pm 50 \mathrm{yr}$ BP) and one pelvis $(40,560 \pm 700 \mathrm{yr} \mathrm{BP})$ indicate that this material consists of at least two individuals whose component parts cannot now be separated without dating each of them individually.

The discovery and extraction of the Jarkov specimen has been thoroughly documented (Mol et al., 2001a) and details need not be repeated here. Information on the discovery of the Markel and Pilot's Site specimens is sparse, although it is clear that each was found on surface as a set of apparently associated remains. Hook was probably essentially complete at the time of discovery in 1990 (Mol et al., 2001b). Unfortunately, its excavation - paid for by a Japanese documentary film crew-was poorly conducted. Soft tissues were certainly present in abundance at the time of discovery, although their completeness cannot now be ascertained. At the time the skull, some vertebra, several long bones, and a few other elements were retrieved for the museum of the Taimyr Nature Reserve in Khatanga. The rest of the Hook skeleton, including most of the animal's hindquarters, was left in the river bank at the spot where the specimen was first encountered. Since then, remains of the carcass have progressively slid down into the river bed. During May, 2001, a number of the remaining elements, including some with adherent soft tissue, were recovered by CME personnel. It is tragic that so much of this excellent specimen has been lost to science.

The dates for the Jarkov and Hook specimens form tight clusters and raise no interpretative problems (Table 3). By contrast, dates for the Markel and Pilot's Site individuals are spread out over many thousands of years. This possibly indicates that more than one individual is present in each case. However, it is important to note that the pertinent dates are near, if not beyond, the limit of reliable radiocarbon dating, and have large counting errors. In the case of Pilot's Site, we discarded the non-finite date $(>49,180 \mathrm{yr}$ BP $)$ when computing the weighted average. Even so, the average, $42,420 \pm 500 \mathrm{yr} \mathrm{BP}$, should not be taken too literally; a conservative estimate for the Pilot's Site skeletal material would simply be that it is $>40,000$ yr BP.

\section{Horse}

Current record and new results. The date of $9010 \pm 140 \mathrm{yr}$ BP (Table 2) for the Nyun'karakutari cranium establishes that horses were still present in Taimyr immediately after the end of the Pleistocene. The youngest within-Pleistocene record for horses in this region is $14,100 \pm 160 \mathrm{yr}$ BP (GIN-3823a, Sulerzhitsky \& Romanenko, 1997). An appreciable gap exists between these terminal or near-terminal Pleistocene dates and the next oldest $-3250 \pm 60 \mathrm{yr}$ вP (GIN-3243, Sulerzhitsky \& Romanenko, 1997)—which lies deep within the Holocene (see Discussion).

Evaluation. Eurasian "caballoid" horses have been oversplit at every possible level (cf. Kahlke, 1999). It is quite clear from the molecular evidence that domesticated horses $(=E$. caballus $)$ incorporate a tremendous breadth of genetic diversity (Vilà et al., 2001), and that multiple species-level divisions within the caballoid group are untenable. We resolve the picture for Taimyr by placing late Quaternary horses from this region within E. caballus, sensu lato. Rusanov (1968) preferred to recognize a different species or subspecies (lenensis) for north Asian horses, but we do not make this distinction. Taimyr horses were quite small, and possible connections with extant Central Asian Przewalski's horse (E. c. przewalskii) as well as socalled E. lambei from Alaska have been noted by Forstén (1988).

\section{Muskox}

Current record and new results. Compared to other parts of the Asian high Arctic (cf. Guthrie, 1990; Stuart, 1991), eastern Taimyr has yielded late Quaternary muskox remains in great abundance. However, little effort has been devoted to developing a good regional chronometric picture for Ovibos. Eighteen 
Table 4. Calibrations of published ${ }^{14} \mathrm{C}$ assays ( $\left.\mathrm{N}=50\right)$ for four megafaunal species from late Quaternary of Taimyr Peninsula and Severnaya Zemlya (Russian Federation)

\begin{tabular}{|c|c|c|c|c|c|c|}
\hline Lab Code ${ }^{1}$ & Sample & Provenance & $\begin{array}{c}\text { Age } \\
\left({ }^{14} \mathrm{C} \text { yr BP }\right. \\
\text { not } \delta^{13} \mathrm{C} \\
\text { corrected })\end{array}$ & $\begin{array}{l}\mathrm{Cal} \mathrm{yr} \\
\text { BP } \\
\text { intercept }\end{array}$ & $\begin{array}{c}\text { Cal yr BP age range } \\
(2 \mathrm{~s} \text { range, Method } \mathrm{B})^{2,3}\end{array}$ & Source $^{4}$ \\
\hline \multicolumn{7}{|l|}{ Mammuthus primigenius } \\
\hline GIN-1828 & Tusk & Lower Taimyra R & $9670 \pm 60$ & 11,150 & $\begin{array}{l}11,200-11,040 @ 50 \% \\
10,960-10,760 @ 46 \%\end{array}$ & (3) \\
\hline GIN-8256 & Tusk & $\begin{array}{l}\text { NE coast of Taimyr P } \\
\text { (Berge Pronchishcheva) }\end{array}$ & $9780 \pm 40$ & 11,200 & 11,230-11,160@100\% & (2) \\
\hline GIN-1495 & Molar & Lower Taimyra $\mathrm{R}$ & $9860 \pm 50$ & 11,230 & $\begin{array}{l}11,300-11,170 @ 90 \% \\
11,340-11,320 @ 6 \%\end{array}$ & (3) \\
\hline GrA-17350 & Mandible & Bikada R & $9920 \pm 60$ & 11,260 & $\begin{array}{l}11,560-11,460 @ 20 \% \\
11,440-11,190 @ 80 \%\end{array}$ & (9) \\
\hline GIN-10508 & Tusk & N'yen'gatiatari R & $10,070 \pm 60$ & 11,780 & $\begin{array}{l}12,150-11,540 @ 83 \% \\
11,510-11,400 @ 9 \%\end{array}$ & (1) \\
\hline GIN-1489 & Molar & Engel'gardt L & $10,100 \pm 100$ & 11,670 & 12,130-11,260@98\% & (3) \\
\hline GIN-11138a & Molar & Kupchiktakh L & $10,200 \pm 40$ & 12,030 & 12,380-11,690@96\% & (1) \\
\hline Beta-148640 & Tusk & Gol'tsovaya R & $10,240 \pm 40$ & 12,020 & $12,380-11,690 @ 97 \%$ & (1) \\
\hline GIN-10507 & Tibia & Nyun'karakutari R & $10,270 \pm 120$ & 12,230 & 12,820-11,690@99\% & (1) \\
\hline GIN-1828k & Radius & Lower Taimyr R & $10,300 \pm 100$ & 12,210 & 12,670-11,630@97\% & (3) \\
\hline GIN-3768 & Limb bone & Nganasanskaya R & $10,680 \pm 70$ & 12,830 & $\begin{array}{l}12,980-12,600 @ 81 \% \\
12,500-12,340 @ 19 \%\end{array}$ & (3) \\
\hline GIN-10552 & Molar & Krasnaya R & $10,790 \pm 100$ & 12,890 & 13,130-12,620@96\% & (1) \\
\hline GIN-3067 & Molar & Baikura Neru B (Taimyr L) & $11,140 \pm 180$ & 13,140 & $\begin{array}{l}13,480-12,830 @ 95 \% \\
13,770-13,690 @ 3 \%\end{array}$ & (3) \\
\hline T-297 & Soft tissues & Mamontovaya $\mathrm{R}$ & $11,450 \pm 250$ & 13,440 & 14,090-12,880@100\% & (3) \\
\hline LU-610 & Tusk & $\begin{array}{l}\text { Severnaya Zemlya Is } \\
\text { (Oktyabr'skoy Revolyutsii Is) }\end{array}$ & $11,500 \pm 60$ & 13,460 & 13,540-13,170@74\% & (3) \\
\hline Beta-148663 & Ulna & Arilakh L & $11,900 \pm 40$ & 13,940 & $\begin{array}{l}13,810-13,630 @ 26 \% \\
14,120-13,790 @ 87 \% \\
13,780-13,640 @ 10 \%\end{array}$ & (1) \\
\hline GIN-10506 & Bone & Bikada R & $12,050 \pm 150$ & 14,080 & $\begin{array}{l}12,420-11,620 @ 73 \% \\
15,320-14,640 @ 27 \%\end{array}$ & (1) \\
\hline GIN- $1783^{5}$ & Limb bone & Baskura P (Taimyr L) & $12,100 \pm 80$ & 14,100 & $\begin{array}{l}14,360-13,820 @ 67 \% \\
15,640-15,320 @ 32 \%\end{array}$ & (2) \\
\hline GIN-2943r & Bone & Severnaya R & $12,260 \pm 120$ & 14,260 & $\begin{array}{l}15,430-14,530 @ 50 \% \\
14,460-14,040 @ 46 \%\end{array}$ & (3) \\
\hline GIN-3242 & Bone & Severnaya R & $12,450 \pm 120$ & 14,720 & 15,460-14,130@100\% & (3) \\
\hline GIN-2677 & Limb bone & Bikada R & $12,780 \pm 80$ & 15,420 & 15,790-14,370@100\% & (3) \\
\hline LU-3827 & Tusk & Sablera C & $13,200 \pm 130$ & 15,870 & $16,450-14,880 @ 100 \%$ & (7) \\
\hline GIN-2758a & Bone & Bol'shaya Balakhnya R & $13,340 \pm 240$ & 16,030 & 16,790-14,900@100\% & (2) \\
\hline Beta-148636 & Femur & Sopochnaya settlement & $13,530 \pm 40$ & 16,290 & 16,770-15,820@100\% & (1) \\
\hline Beta-148642 & Femur & Sabler C & $15,330 \pm 50$ & 18,390 & 18,970-17,850@100\% & (1) \\
\hline GIN-3130 & Bone & Bederbo-Tarida $\mathrm{R}$ & $16,330 \pm 100$ & 19,470 & 20,130-18,870@100\% & (2) \\
\hline Beta-148646 & Molar & Bol'shaya Balakhnya R & $18,140 \pm 60$ & 21,610 & $22,300-20,960 @ 100 \%$ & (1) \\
\hline LU-654b & Tusk & $\begin{array}{l}\text { Severnaya Zemlya Is } \\
\text { (Oktyabr'skoy Revolyutsii Is) }\end{array}$ & $19,270 \pm 130$ & 22,850 & 23,640-22,110@100\% & (3) \\
\hline LU-688 & Tusk & $\begin{array}{l}\text { Severnaya Zemlya Is } \\
\text { (Oktyabr'skoy Revolyutsii Is) }\end{array}$ & $19,970 \pm 110$ & 23,660 & {$[24,400]-22,920 @ 100 \%$} & (3) \\
\hline UtC-8137, 8138, 8139 & Bone & Bol'shaya Balakhnya R & $20,200 \pm 80^{6}$ & 23,920 & {$[24,610]-23,170 @ 100 \%$} & (5) \\
\hline \multicolumn{7}{|l|}{ Ovibos moschatus } \\
\hline GIN-3803 & Bone & Logata R & $2700 \pm 70$ & 2780 & $3000-2710$ & (2) \\
\hline GIN-25529 & Skull & Pronchishchev B & $2900 \pm 60$ & 3040 & $3260-2850 @ 100 \%$ & (1) \\
\hline GIN-2945 & Skull & Chelyuskin C & $2920 \pm 50$ & 3080 & $\begin{array}{l}3260-2920 @ 95 \% \\
2910-2870\end{array}$ & (2) \\
\hline$----^{7}$ & Skull & Chelyuskin C & $3800 \pm 200$ & 4190 & 4650-3690@96\% & (8) \\
\hline GIN-3131 & Skull & Bol'shaya Balakhnya R & $12,150 \pm 40$ & 14,120 & $\begin{array}{l}15,360-14,620 @ 38 \% \\
14,370-14,040 @ 52 \%\end{array}$ & (2) \\
\hline Beta-148653 & Skull & Sabler C & $15,710 \pm 50$ & 18,850 & 19,450-18,290@100\% & (1) \\
\hline GIN-3239 & Skull & Agapa R & $16,080 \pm 100$ & 19,180 & 19,820-19,580@100\% & (2) \\
\hline GIN-1815 & Skull & Lower Taimyra $\mathrm{R}$ & $17,800 \pm 300$ & 21,160 & $22,110-20,250 @ 100 \%$ & (2) \\
\hline GIN-3140v & Skull & Sabler C & $17,800 \pm 160$ & 21,160 & 21,910-20,430@100\% & (2) \\
\hline Beta-148628 & Horn & Sabler C & $18,310 \pm 70$ & 21,820 & $22,510-21,150 @ 100 \%$ & (1) \\
\hline Beta-148627 & Atlas & Sabler C & $19,230 \pm 80$ & 22,900 & 23,650-22,190@100\% & (1) \\
\hline Beta-148654 & Skull & Bol'shaya Balakhnya R & $19,640 \pm 70$ & 23,360 & {$[24,120]-22,650 @ 100 \%$} & (1) \\
\hline
\end{tabular}




\begin{tabular}{|c|c|c|c|c|c|c|}
\hline Lab Code ${ }^{1}$ & Sample & Provenance & $\begin{array}{c}\text { Age } \\
\left({ }^{14} \mathrm{C} \text { yr BP }\right. \\
\text { not } \delta^{13} \mathrm{C} \\
\text { corrected })\end{array}$ & $\begin{array}{c}\mathrm{Cal} \mathrm{yr} \\
\mathrm{BP} \\
\text { intercept }\end{array}$ & $\begin{array}{c}\text { Cal yr BP age range } \\
(2 \mathrm{~s} \text { range, Method } \mathrm{B})^{2,3}\end{array}$ & Source $^{4}$ \\
\hline \multicolumn{7}{|l|}{ Equus caballus } \\
\hline GIN-2744 & Bone & Bol'shaya Balakhnya R & $2150 \pm 200$ & 2140 & 2710-1710@100\% & (2) \\
\hline GIN-3243 ${ }^{8}$ & Skull & Agapa R & $3250 \pm 60$ & 3470 & $3640-3340$ & (2) \\
\hline GIN-10509 & Maxilla & Nyun'karakutari R & $9010 \pm 140$ & 10,200 & $10,500-9680$ & (1) \\
\hline GIN-3823a & Bone & Logata $\mathrm{R}$ & $14,100 \pm 160$ & 16,910 & 17,510-16,330@100\% & (2) \\
\hline Beta-148659 & Radius-ulna & Taimyr L & $17,950 \pm 60$ & 21,310 & 21,980-20,650@100\% & (1) \\
\hline GrA-17351 & Skull & Arilakh L & $18,090 \pm 80$ & 21,500 & 22,190-20,850@100\% & (1) \\
\hline GIN-3140b & Bone & Bol'shaya Balkhnya R & $18,300 \pm 200$ & 21,740 & $22,550-20,970 @ 100 \%$ & (2) \\
\hline $\begin{array}{l}\text { Bison priscus } \\
\text { Beta-148623 }\end{array}$ & Horn sheath & Popigay R & $8810 \pm 40$ & 10,040 & 10,160-9710@100\% & (1) \\
\hline \multicolumn{7}{|c|}{$\begin{array}{l}{ }^{1} \text { Reporting laboratory acronyms: Beta, Beta Analytic, Inc. (Florida, U.S.A.); GIN, Geological Institute, Russian Academy of Sciences } \\
\text { (Russia); LU, Geographical Research Institute, St Petersburg State University (Russia); GrA, Groningen AMS, Center for Isotope } \\
\text { Research (Netherlands); T, Trondheim, Radiological Dating Laboratory (Norway); UtC, Utrecht van de Graff Laboratorium } \\
\text { (Netherlands). } \\
{ }^{2} \text { Method B in CALIB v4.3 package (Stuiver et al., 1998) was used for all calibration computations, using assumptions of atmospheric }{ }^{14} \mathrm{C} \\
\text { model; all results rounded to nearest } 10 \mathrm{yr} \text { Cal BP for each Beta Analytic date was computed from the measured }{ }^{14} \mathrm{C} \text { date using } \\
\text { lab-supplied } \delta^{13} \mathrm{C} \text { value. Multiple intercepts have been averaged. Calibration for each GrA and UtC date was calculated directly from } \\
\text { lab-supplied date }\left(\delta^{13} \mathrm{C} \text { corrected). All other dates listed under "Age }\left({ }^{14} \mathrm{C} \text { yr BP)" in this table are uncorrected measured }{ }^{14} \mathrm{C} \text { dates, and }\right.\right. \\
\text { therefore differ slightly from listings in Table } 1 \text {. To convert to cal yr BP, } \delta^{13} \mathrm{C}=-25 \cdot 0 \text { was assumed unless real value known. } \\
{ }^{3} \text { Probability estimate of true date being within a certain cal yr range, as provided by CALIB v4.3. Estimates of }<3 \% \text { not reported. Dates in } \\
\text { square brackets are linear extensions beyond INTCAL98 calibration curve's current terminus }(c \text {. } 20,265 \mathrm{BP}) \text {. } \\
{ }^{4} \text { Sources: (1) this paper; (2) Sulerzhitsky, 1995; Sulerzhitsky \& Romanenko, 1997, 1999; (3) Vasil'chuk et al. (1997); (4) Stuart (1991); (5) } \\
\text { University of Utrecht/Mammuthus project; (6) Vereshchagin \& Tikhonov (1999); (7) Möller et al. (1999); (8) Vereshchagin \& Baryshnikov } \\
\text { (1984); (9) Reumer \& Mol (2001). } \\
\text { 5Stuart (1991) lists Cape Sabler as locality for this specimen. } \\
{ }^{6} \text { Weighted average of } 3 \text { dates; see Table 3. }\end{array}$} \\
\hline
\end{tabular}

new dates for muskox are reported in Tables 1 and 2 (including one replicate), and they cover a lengthy interval $-42,590 \pm 1240$ to $2900 \pm 60 \mathrm{yr}$ BP. Partial or complete muskox skeletons are probably commonly encountered, although rarely collected as such. In any case, the partial skelteon from the Popigay valley (Table 3 ) is the only one on record with a ${ }^{14} \mathrm{C}$ date.

Evaluation. The late Pleistocene range of Ovibos, at its maximum, extended from North America through northern Asia to western Europe (Kurtén \& Anderson, 1984). Eurasian and New World muskoxen are usually considered to constitute one widely distributed species, although one of us (A.T.) prefers to distinguish the Eurasian population at the subspecies level (O. moschatus pallantis; see Tikhonov, 1998).

It was previously believed that muskoxen were extirpated in Eurasia around the end of the Pleistocene, and that populations of $O$. moschatus survived in the New World only (cf. Martin \& Guilday, 1967). However, it is now clear that the story must be more complex, because there is ample evidence for muskox presence in Taimyr (and, less persuasively, in southern Siberia) during the late Holocene. The first indication of this was Vereshchagin's (1971; see also Vereshchagin \& Baryshnikov, 1984) report of dates of $3800 \pm 200$ and $2900 \pm 95 \mathrm{yr}$ BP for two skulls that had been surfacecollected on Cape Chelyuskin in 1948. These results were later confirmed by Harington (1970). Recently, another young date-at $2700 \pm 70 \mathrm{yr}$ BP (GIN-3803; Sulerzhitsky \& Romanenko, 1997), the youngest so far-was reported for a muskox specimen from the middle channel of the Logata, a tributary of the Upper Taimyra. GIN 255290 (Table 2), based on a CME specimen from Pronchishchev Bay, is statistically indistinguishable from this result. Exclusive of the Taimyr record, the latest date for Ovibos in Eurasia is $10,750 \pm 50 \mathrm{yr}$ BP (LU-1666), for a specimen from Kotel'nyy I., New Siberian Islands (Sulerzhitsky \& Romanenko, 1997).

Interestingly, Vereshchagin (1971) noted the presence of perfectly circular holes (including an alleged bullet hole) in one of the Chelyuskin skulls. He speculated that the muskox may even have been known to the first Russian trappers and explorers who penetrated the Taimyr region in the early 1600 s (Belov, 1956). There is, however, no reliable evidence to this effect. (But see Spassov, 1991 and Lent, 1996, on intriguing but ambiguous archeological evidence 
of muskox survival at the beginning of the first millennium AD.) At present, it is possible only to say that the cause of the final disappearance of muskoxen in Asia is not known, and that there is a substantial gap between the last Pleistocene records for Asian O. moschatus and the much later records for Taimyr (see Discussion).

\section{Bison priscus}

Current record and new results. In contrast to penecontemporaneous Alaskan sites (cf. Kurtén \& Anderson, 1984; Guthrie, 1990), fossils of steppe bison are not common in Taimyr. Thus any new data on the temporal distribution of Bison priscus in this part of northern Asia are welcome. The three dates reported here are distributed over a lengthy interval (Table 1). The earlier two, $39,760 \pm 870$ and 45,320 $\pm 1740 \mathrm{yr} \mathrm{BP}$, are the oldest finite dates that have been reported for Taimyr bison. The third date, $8860 \pm 40 \mathrm{yr} \mathrm{BP}$, which is based on a partial horn sheath, is currently the latest published record for $B$. priscus anywhere in continental Eurasia. It is also substantially younger than the eight other published dates for Taimyr bison, all of which are $>27,000 \mathrm{yr}$ BP.

Although the sheath is well preserved it is quite incomplete, measuring only $40 \mathrm{~cm}$ along its centreline parallel to the arc of curvature. This value suggests an animal of moderate rather than large size.

Evaluation. Our new evidence establishes that B. priscus still existed in the Khatanga catchment at the beginning of the Holocene. This also appears to be true for southern Siberia (e.g., $8960 \pm 60 \mathrm{yr}$ BP (GIN-96) for bison from the archaeological site of Ust' Belaya, Angara basin (Ermolova, 1978; Tikonov, 1999)). Slightly older dates have been recorded for bison specimens from the Lower Kolyma, Indigirka, upper Yenisei, and Selenga drainages (see Stuart, 1991; Tikonov, 1999). The youngest European fossils assigned to B. priscus, from southern France, are associated with dates of 11-12,000 yr BP (Stuart, 1991, 1999).

It should be noted that the taxonomic status of the steppe bison is somewhat ambiguous. Bison priscus is the usual default taxon used to attribute isolated or incomplete bovin fossils from late Quaternary contexts in north-central Siberia. This species is usually regarded as being distinct from Bison bison (the American bison) and Bison bonasus (the living European wisent), although all three are very closely related (Guthrie, 1990; Stuart, 1991). Certainly, distinguishing among late Quaternary Bison priscus, $B$. schoetensacki, B. latifrons, and B. bison exclusively on the basis of horn core morphology seems a suspect enterprise. Adding further doubt to the utility of maintaining such an array of names is the assertion that B. priscus may have been able to interbreed (!) with these other, allegedly distinct species (cf. Kurten $\&$ Anderson, 1980). Finally, some authors believe that
$B$. priscus survived as such into very recent times (Vereshchagin \& Baryshnikov, 1984), in which case it cannot be considered to be a "prehistoric" extinction. However, in our view the evidentiary grounds for this belief are slim.

\section{Rangifer tarandus}

Current record and new results. In the past, reindeer fossils were rarely considered worth dating. Indeed, we were able to find only nine published dates on Rangifer material for the entire Asian Arctic periphery, and only one of these concerns a specimen from Taimyr (5090 \pm 80 yr BP, GIN-3132; specimen from Bol'shaya Balakhnya basin). Although only three new dates are offered here, they are sufficient to confirm that $R$. tarandus was present in Taimyr at least as early as $36,000 \mathrm{yr} \mathrm{BP}$.

Evaluation. Our single early Holocene record ( $8710 \pm 60 \mathrm{yr} \mathrm{BP}$, weighted average) falls within a crucial period just after the Pleistocene/Holocene transition (see Discussion). Reindeer remains are exceedingly common in Taimyr, and it would not be difficult to fill out the chronometric record for $R$. tarandus if that were considered to be a priority.

\section{Other Taxa}

Current record and new results. Species that are extant but rarely encountered in paleontological contexts in northern Asia still merit dating because radiometric information may help with assessing their previous synchronic ranges and other patterns of interest. We report here on AMS dates for moose (Alces alces) and wolf (Canis lupus) (Table 1).

The date on the Sopochnaya moose frontal, $4050 \pm 40 \mathrm{yr} \mathrm{BP}$, is by far the youngest of the very few dates reported for Taimyr Alces. The canid specimen was of interest because its comparatively small size and characters of the cheekteeth and skull raised the possibility that it might be a domesticated or semidomesticated animal. We believe that its replicate dates- $-16,310 \pm 50$ and $16,670 \pm 70 \mathrm{yr}$ вP-render this argument improbable, and we therefore allocate the specimen to Canis lupus per se. Although the dating is regarded as reliable, it should be noted that the two age estimates for the wolf skull do not overlap at $2 \sigma$.

Evaluation. The radiometric record for moose in Late Pleistocene Asia is sufficient to indicate that it once ranged over a substantial portion of northern Siberia (Kahlke, 1999), presumably during favourable periods when the tree line was situated to the north of its present position. Nevertheless, it is unsurprising that Alces, a browser, is rarely encountered palaeontologically in the high Arctic. The presence of moose in Taimyr during the Karginsk interstadial is supported by three dates listed in the Sulerzhitzky \& Romanenko 
(1997) compendium, all of which are in excess of $30,000 \mathrm{yr}$ BP. A fourth date reported here $(47,900+1000 /-9000$ yr BP, GrA-17346) may also be regarded as supportive of interstadial presence of moose.

No other extinct megafaunal species have been recorded for Taimyr, even though several taxa (e.g., Saiga tatarica, Panthera leo) are known to have occurred elsewhere in Siberia at roughly similar latitudes. The absence of a record for woolly rhino is unsurprising, given the rarity of this species at all times and places (Kahlke, 1999). Examination of several alleged rhino specimens found by or reported to the CME team in the course of the 2000 expedition failed to reveal any definite cases. A Coelodonta skull from the Gydan Peninsula, just to the west of Taimyr, is on display in the museum in Dudinka. However, it has not been described or dated (D. Mol, pers. obs.). Presumably it is just a matter of time - and prospecting - until the presence of Coelodonta in Taimyr is confirmed.

A small number of micromammal remains (all extant species), mostly attributable to the collared lemming (Dicrostonyx torquatus), Arctic hare (Lepus arcticus), and polar fox (Alopex lagopus), were collected during 2000 but have not been dated.

\section{Discussion}

\section{Distribution of dates in correlation with latitude}

Sulerzhitsky \& Romanenko (1999) noted that "last" occurrence dates for woolly mammoths are younger in the northern part of Taimyr than in the south, implying that the species managed to persist longer at higher latitudes. The new dates reported here may be said to support this observation, with the proviso that withininterval ranges are substantial (Figure 4; see also Table 4). Of some interest is the fact that virtually all Taimyr mammoth remains having dates younger than $12-13,000 \mathrm{yr}$ BP come from localities north of the $74^{\circ}$ parallel.

There is a complementary interbasinal difference in date distributions within the Pleistocene that may also be instructive (cf. relevance of basinal analysis in Agenbroad, 1984). To investigate this difference we compared date pools for the Khatanga and Taimyra basins, using megafaunal dates older than 10,000 yr BP (for sources, see Table 4 and compendia noted therein). Of 163 dates compiled for this purpose, the Khatanga basin is represented by 93 entries (range: 11,200$53,170 \mathrm{yr} \mathrm{BP}$ ) and the Taimyra basin by 70 (range: $10,070-46,100 \mathrm{yr} \mathrm{BP})$. Although ranges are very similar, means and distributions are not. The mean for the Khatanga sample, 33,460 $\mathrm{yr} \mathrm{BP}$, is considerably older than that for the Taimyra sample, which is only $24,260 \mathrm{yr}$ BP. The Mann-Whitney $U$ statistic indicates that the two distributions are significantly different $(U=1745 \cdot 0 ; P<0 \cdot 0001)$. Persistence in the north is also suggested by the tallies in Table 5 , which presents a

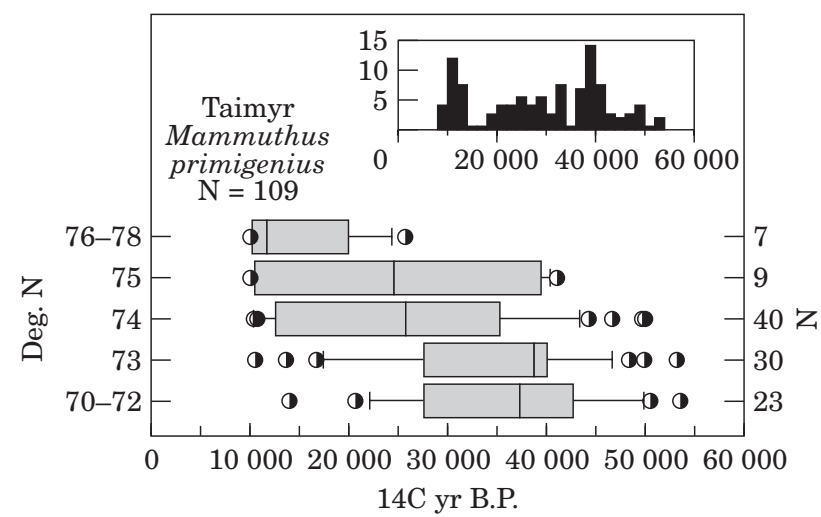

Figure 4. Box plots, dated specimens of Mammuthus primigenius $(N=109)$ from Taimyr Peninsula and northern Siberian lowlands north of $70^{\circ} \mathrm{N}$ (various sources). Specimens grouped according to provenances within intervals of approximately $1^{\circ}$ width (e.g., all provenances situated between $74^{\circ} 0^{\prime}-74^{\circ} 59^{\prime}$ are placed within the $74^{\circ}$ bracket). Some intervals combined because of paucity of specimens. Latitudinal position had to be inferred in cases in which provenances were vaguely stated in the original reports. For each $1^{\circ}$ interval, box plot summarizes mean (vertical line), 50th percentile limits (grey box), 90th percentile limits (nail lines outside box), and positions of outliers (half-filled circles). Distribution of dates given by histogram (upper right); accuracy of older age estimates (before 30,000 yr BP) should be regarded as doubtful (see text).

As noted by Sulerzhitsky \& Romanenko (1999), there is an empirical trend toward younger mean dates per interval as one moves northward in Taimyr, although within-interval ranges are substantial.

slightly different combination of mammoth dates by basin (or island).

On closer inspection, however, it is evident that the mammoth dates control the statistical location of the two distributions. If mammoths and poorly sampled taxa (moose, reindeer, wolf) are removed, withinPleistocene dates for the remaining megafauna $(N=52)$ appear to have very similar distributions and the Mann-Whitney statistic is not significant $(P=0 \cdot 1288)$. Although this test does not explain what happened to mammoth populations in these areas, one possibility is that mammoths became rarer in the southern (Khatangan) part of the Taimyr Peninsula after $20,000 \mathrm{yr} \mathrm{BP}$, but remained more numerous in the northern (Taimyran) part until the time of extinction or "last" occurrence. Perhaps this was because large influxes of meltwater left large parts of the northern Siberian lowlands waterlogged (or perhaps even underwater) for a long period after the end of glaciation.

\section{Radiocarbon dating and timing of extinctions}

Radiocarbon dates are routinely used to fix times of extinction during the late Quaternary (e.g., MacPhee et al., 1999; Gonzalez et al., 2000). The governing principle is that, given a sufficiently dense dating record for a now-extinct species, "last" occurrence dates can be meaningfully used to define the interval in which disappearance probably took place (cf. McFarlane, 1999). However, sampling intensity is only the first of 
Table 5. Mammuthus primigenius, 115 radiocarbon ages for specimens from Taimyr Peninsula and Severnaya Zemlya (Russian Federation) ${ }^{1}$

\begin{tabular}{lccccc}
\hline $\begin{array}{l}\text { Ages }\left({ }^{14} \mathrm{C} \text { yr B.P.) }\right. \\
\text { by Region }\end{array}$ & $\begin{array}{c}\text { Khatanga } \\
\text { Basin }\end{array}$ & $\begin{array}{c}\text { Pyasina } \\
\text { Basin }\end{array}$ & $\begin{array}{c}\text { Taimyra } \\
\text { Basin }\end{array}$ & $\begin{array}{c}\text { Severnaya Zemlya } \\
\text { \& NE Coast }\end{array}$ & $\begin{array}{c}\text { Statistics for } \\
\text { Total Sample }\end{array}$ \\
\hline$N$ & 61 & 3 & 46 & 5 & 115 \\
Mean (of $N$ dates) & 34,980 & 26,030 & 22,860 & 17,110 & 29,120 \\
S.D. & 10,530 & 6150 & 11,450 & 6340 & 12,370 \\
Minimum & 10,200 & 20,400 & 9670 & 9780 & 9670 \\
Maximum & 53,170 & 32,600 & 46,100 & 25,030 & 53,170 \\
\hline
\end{tabular}

${ }^{1}$ For dating sources, see Table 4.

${ }^{2}$ Dates rounded to nearest $10 \mathrm{yr}$.

${ }^{3}$ Replicate dates on same specimen or individual are averaged (see Table 3).

several issues that must be considered in using radiocarbon dates for this purpose. For example, one important concern is that, from an epistemological standpoint, any given "last" occurrence date is merely a provisional and minimum estimate of the true extinction date (MacPhee \& Flemming, 2001). Except in the most contrived hypothetical cases, extinction dates can only be presented in the form of probability statements (Signor \& Lipps, 1982).

Another concern of special relevance to late Quaternary paleontology and archeology is the problem of "dating plateaus" (e.g., Long et al., 1998; Fiedel, 1999). If, as once believed, the amount of ${ }^{14} \mathrm{C}$ formed in the upper atmosphere had been effectively constant over time, one radiocarbon year would be approximately equal to one absolute (calendar) year (Geyh \& Schleicher, 1991). As much empirical evidence shows, there is no equivalence of this sort across any substantial time period, largely because of considerable flux in the amount of cosmogenic ${ }^{14} \mathrm{C}$ entering the carbon reservoir (van der Plicht, 2000; Beck et al., 2001). For present purposes the chief complication is that a given radiocarbon age estimate (i.e., mean age \pm 1 or $2 \sigma$ ), when graphed against a standardized calibration curve like INTCAL98, may intersect the curve at several points. If that happens, the resulting calibrated range will consist of several apparently equipotential solutions, their number and width depending on the shape of the calibration curve at the point(s) of intersection. In practical terms, this is equivalent to increasing the size of the error term, often to the extent that meaningful interpretation of times series becomes impossible. Thus in the case of the late Quaternary extinctions in the New World (Beck, 1996), most "last" occurrence dates for now-extinct megafauna fall within the upper part of the "Younger Dryas plateau" (hereafter, YD plateau), which is formally defined as persisting from 10,800 to $9800 \mathrm{yr}$ BP $(12,500$ to 10,000 cal yr BP) when $\Delta^{14} \mathrm{C}$ fell by $80 \%$ (Kitagawa \& van der Plicht, 1998). Any radiocarbon date that falls within the YD plateau will be consistent with a wide span of calendar years (Fiedel, 1999). Thus in the case of North American losses, all that can be reasonably said at present is that the majority of megafaunal extinctions took place sometime around $13,500-12,500 \mathrm{cal}$ yr BP, but within an additional envelope of uncertainty that is not less than \pm 1000 cal $\mathrm{yr}$ wide. This is an unhelpful conclusion, as certain explanations of the extinctions depend upon rapid scheduling and close timing in the loss of different species (MacPhee \& Marx, 1997; Martin \& Steadman, 1999).

Interestingly, the situation in northern Eurasia may be somewhat more promising, depending on when or whether the various species of interest actually became extinct. In contrast to the North American case, a number of reported "last" occurrence dates for mainland Asian megafauna lie within the terminal part of, or just after, the YD plateau. These dates fall within the earliest part of the Holocene, a period that was less affected by abrupt shifts in the value of $\Delta^{14} \mathrm{C}$. In principle, this may help to constrain more narrowly the interval in which the extinctions took place. In Table 4, for example, dates lying between $c .9800$ and $8800 \mathrm{yr}$ вP have corresponding cal yr BP ranges that are from $25 \%$ to $90 \%$ smaller (in total span) than those of dates between $c .10,250$ and 11,250 yr BP with roughly similar sigmas (cf. B-148623 and GIN-8256 vs. B-148640 and GIN-3768). Although these examples are merely illustrative, they raise the hope that some late Quaternary extinctions will not be as difficult to constrain as others.

\section{The significance of "gaps"}

In the present sample, six (11\%) of the 55 non-replicate AMS dates are older than 40,000 yr BP. The corresponding figure for a pool of 112 previously-reported dates is $22(20 \%)$ (Figure 2(a)-(c)). Such high proportions of "old" dates are not unusual for surfacecollected samples from the high Arctic periphery (Sulerzhitsky \& Romanenko, 1999). Because bone collagen lasts remarkably well in this region, beautifully preserved specimens frequently register little or no measurable radiocarbon activity, indicating that their true age lies beyond the analytical range of current techniques. Also, the relatively high frequency of radioactively dead (or nearly dead) specimens indicates that contamination of bone collagen by "young" radiocarbon sources, such as humic acids, either 
does not occur or is inconsequential (Sulerzhitsky \& Romanenko, 1999).

Nevertheless, one cannot be uniformly confident of the meaning of dates from different parts of the radiocarbon range. Radiocarbon dates that are within the range of tree-ring calibration $(<11,860 \mathrm{cal}$ yr $\mathrm{BP})$ have a potentially precise solution in cal yr, even if, as discussed above, systematic errors may affect overall accuracy. However, dates that are considerably older than $30,000 \mathrm{yr}$ BP are subject to greater uncertainties. These considerations make a difference to the evaluation of certain features of the Taimyr record, especially with regard to the interpretation of apparent "gaps".

Gaps are detected empirically: in a good record, they are anomalous intervals for which there are few or no dates. However, their inductive significance increases if (a) the gaps are lengthy, and (b) they occur at the same time in the chronometric records of other regions in which the target species existed, and (c) other plausible reasons for the gaps can be eliminated. This last criterion is always critical, as the following discussion shows.

(a) 36,000-33,000 yr BP gap. This apparent anomaly, obvious in the combined date pool (Figure 2(c)), has two aspects: (a) near absence of dates falling within the range 36,000-33,000 $\mathrm{yr} \mathrm{BP}$, and (b) excess of observations on either side of this period. Only three mean dates in the 188-date database fall within this interval, yielding an incidence of $\sim 1$ mean date/thousand years for this period. By contrast, the overall incidence for the combined sample is 3.7 mean dates/thousand years (range, c. 53,000-2000 yr BP). By itself this difference is of little interest, and the gap effectively disappears if $2 \sigma$ error bars are taken into account. However, there is the second feature to consider, i.e., the relatively large number of dates falling on either side of the gap: 24 between 33,000-30,000 yr BP and another 22 between $39,000-36,000 \mathrm{yr} \mathrm{BP}$, or twice the average number expected per thousand years. If there were isometry between radiometric and calendrical measures of time, then under conditions of random sampling the gap could be interpreted as a period of real megafaunal absence, sandwiched between periods of greater-thannormal population density. However, the calibration presented by Beck et al. (2001) indicates that the apparent anomaly under discussion here falls completely within the period of greatest $\Delta^{14} \mathrm{C}$ fluctuation, c. 44,000-40,000 cal yr BP, raising the possibility that the rarefaction is an artifact. Indeed, as graphed by Beck et al. (2001), see-sawing in the $\Delta^{14} \mathrm{C}$ trend during this period results in a true chronometric inversion, which throws doubt on the actual value of any date from this period. Possibly, rapid shifts in $\Delta^{14} \mathrm{C}$ values are the root cause of both the rarefaction of variates seen in the mid-part of the range as well as the concentrations at the ends, although we have not modelled this point.
Significantly, this rarefaction/concentration is not detectable interregionally. In a collation of 143 published dates for mammoth fossils from Yamal, Yakutia, and the northeastern part of the Far East (data not shown), we found no clear evidence of a hiatus between 35,000-33,000 yr BP, nor any unusual concentration of dates in the intervals immediately before and after. Nor is rarefaction seen in a similar dataset assembled by Sulerzhitsky \& Romanenko (1997, 1999). Kuznetsova et al. (2001) report a significant gap in the record (mammoths only) for the New Siberian Islands, but the gap is much longer $(44,000$ $36,000 \mathrm{yr}$ BP) than the one seen in the Taimyr data or elsewhere in the Arctic periphery. While factors local to Taimyr (or, for that matter, the New Siberian Islands) cannot be completely discounted as a cause for the gap, at present there is no reason to regard it as more than a sampling error or possibly a bias produced by rapid $\Delta{ }^{14} \mathrm{C}$.

There are additional apparent gaps in the earliest part of the record, $>45,000 \mathrm{yr} \mathrm{BP}$, but we see no reason to consider them in view of the serious doubts attending the reality of the gap at $36,000-33,000 \mathrm{yr}$ BP.

(b) 21,000-19,500 cal yr BP gap. The second apparent gap is best seen in Figure 5, which plots the calibrated intercepts of 50 dates less than $c .20,000 \mathrm{yr}$ BP presented in Table 4 . When the extremes of the $2 \sigma$ ranges are considered, the gap closes noticeably, although the short interval between 19,750 and 20,250 cal yr BP remains patent. Kuzentsova et al. (2001) have found a similar gap in the mammoth record for the New Siberian Islands and the Bykovskiy Peninsula southeast of Lena Delta. The paucity of records may be due to environmental conditions at the time. During the LGM, Taimyr may have experienced extreme polar desert conditions (Siegert \& Marsiat, 2001), perhaps including some amount of terrestrial-ice cover (but this is debated; cf. Grosswald, 1998; Möller et al., 1999; Grosswald \& Hughes, 1999). Other regions along the high Arctic coast are similar, in that there are few dates on fauna which correlate with the period that includes the LGM and its immediate aftermath. Indeed, it is pertinent to note that the entire period between 21,000 and $17,000 \mathrm{cal}$ yr BP is underrepresented in our date compilations (cf. additional small gap in the interval $18,000-17,000$ cal $\mathrm{yr}$ BP). It should be noted that the calibration curve for this part of the record is derived from paired/U-series dates on corals, and is subject to additional systematic errors that do not apply to the dendrochronological part of the curve (van der Plicht, 2000). Thus, although it is intriguing that Taimyr might have been less frequented by megafauna during the coldest part of the Sartan (=Late Weichselian), the radiocarbon evidence for this is far from conclusive.

(c) 8000-4000 yr BP gap. This last gap is different from the others in that it appears in all relevant records (including ones outside Taimyr) and falls within the 


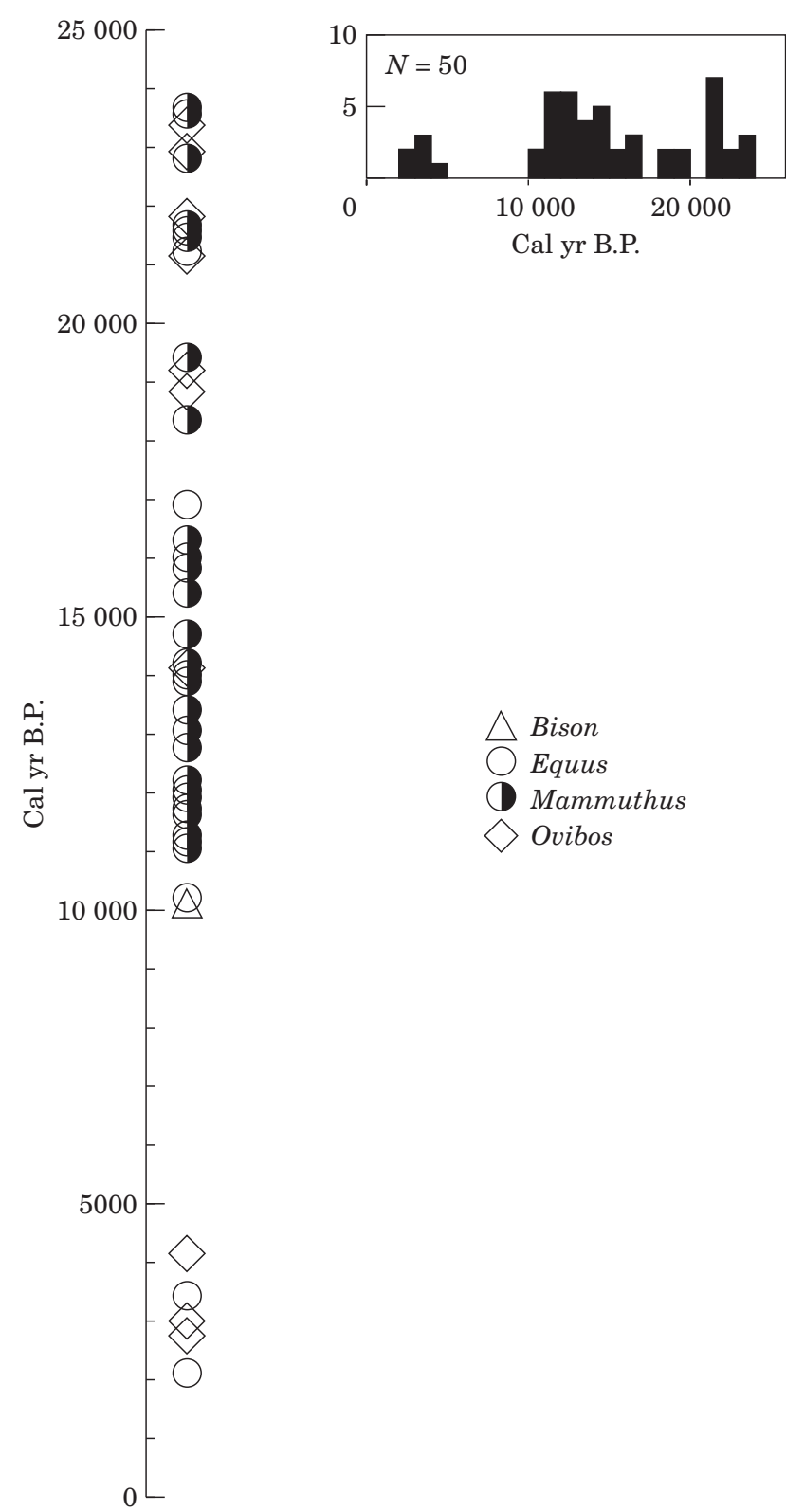

Figure 5. Distribution of calibrated dates $(N=50)$ for selected Taimyr megafauna lying within INTCAL98 (Stuiver et al., 1998) calibration range (to $24,000 \mathrm{cal} \mathrm{yr} \mathrm{BP}$ ). Dates shown as intercepts only, to simplify graphic presentation. See Table 4 for additional information on dates, provenances, and calibrations. Only species or distinct populations that eventually became extinct within the high Arctic periphery are included (Mammuthus primigenius, Bison priscus, Ovibos moschatus, Equus caballus). Modern reintroductions not considered. Histogram shows distribution of intercepts grouped in intervals of 2000 years.

Two conspicuous rarefactions in megafaunal presence in Taimyr seem to be present $(21,000-19,500 \mathrm{cal}$ yr BP, and 10,000-4,000 cal yr BP). The earlier gap (apparently coeval with the LGM and its immediate aftermath) almost disappears when $2 \sigma$ ranges of individual dates are considered (Table 4). Its significance is therefore ambiguous at this time, although it is important to note that few megafaunal dates from any part of the high Arctic periphery fall within or immediately after the LGM. The early Holocene gap is more robust and can be correlated with the late Quaternary megafaunal extinctions in Eurasia. See text and Figure 6. part of the calibration curve controlled by the dendrochronological standard. It therefore is not likely to be a result of biased sampling, taphonomic effects, or heretofore undetected $\Delta{ }^{14} \mathrm{C}$ flux. However, due to the paucity of observations, the gap requires close inspection and interpretation. To increase resolution, multiregional radiocarbon records were collated for seven megafaunal taxa for the period after $18,000 \mathrm{yr}$ BP (Figure 6). This was necessary because the persistence times of taxa other than Mammuthus in specific areas cannot be adequately demonstrated empirically, due to limited sampling. For example, it is known that Bison existed in Taimyr around 40,000 $\mathrm{yr} \mathrm{BP}$, and a string of later dates confirm that this species was also there at $27,600 \pm 400$ yr BP (Sulerzhitsky \& Romanenko, 1999). Thereafter, however, there is no later record for Bison in Taimyr until $8810 \pm 60 \mathrm{yr}$ BP (B-148623). It is possible but surely unlikely that Bison was absent from Taimyr for nearly 20,000 years. Rather, it appears that, by chance, remains of chronometrically more recent bison have not been selected for dating. This seems to be borne out by the limited dating records for northern Yakutia, which establish that Bison persisted in highlatitude Siberia until nearly the end of the Pleistocene (Stuart, 1991). Similar arguments apply to the other taxa considered: although regional records are individually very spotty, in combination they indicate that individual species were present along the high Arctic periphery for tens of thousands of years prior to the end of the Pleistocene. The gray boxes (screens) on each species' timeline represent currently undocumented portions of their separate histories (see Figure 6).

It is useful to discuss the Pleistocene/PHB and the later Holocene portions of these collated records separately. For mainland woolly mammoths, steppe bison, and horse, the within-Pleistocene radiocarbon record for northernmost Asia continues up to, or just beyond, the end of the epoch (c.9600-8800 yr BP, corresponding to $c .11,000-10,000 \mathrm{cal} \mathrm{yr} \mathrm{BP}$, in round figures), although dating is dense only for Mammuthus. It is plausible that Ovibos and Coelodonta might have truly terminal Pleistocene records as well, but if so the relevant specimens have not yet been found and dated. At present, empirical records for muskox and woolly rhino in Asia end in the late 11th and early 15th millennia BP respectively. (Kahlke 1999 notes the existence of an unpublished date of $c .11,000 \mathrm{yr}$ BP for a Coelodonta specimen from Jilin, China, but this date needs to be verified before being accepted.) The reindeer record is very poor, although there are three dates (each from a different region) that fall into the interval between the mid-10th millennium and the earliest part of the 8th millennium BP (c. 11,000-9500 cal yr BP). There are no latest Pleistocene dates for Alces. Nevertheless, on the whole one's perception is that all of the megafaunal species present in northernmost Asia at the beginning of the period covered by radiocarbon dating were still there at or very near the end of the Pleistocene. 


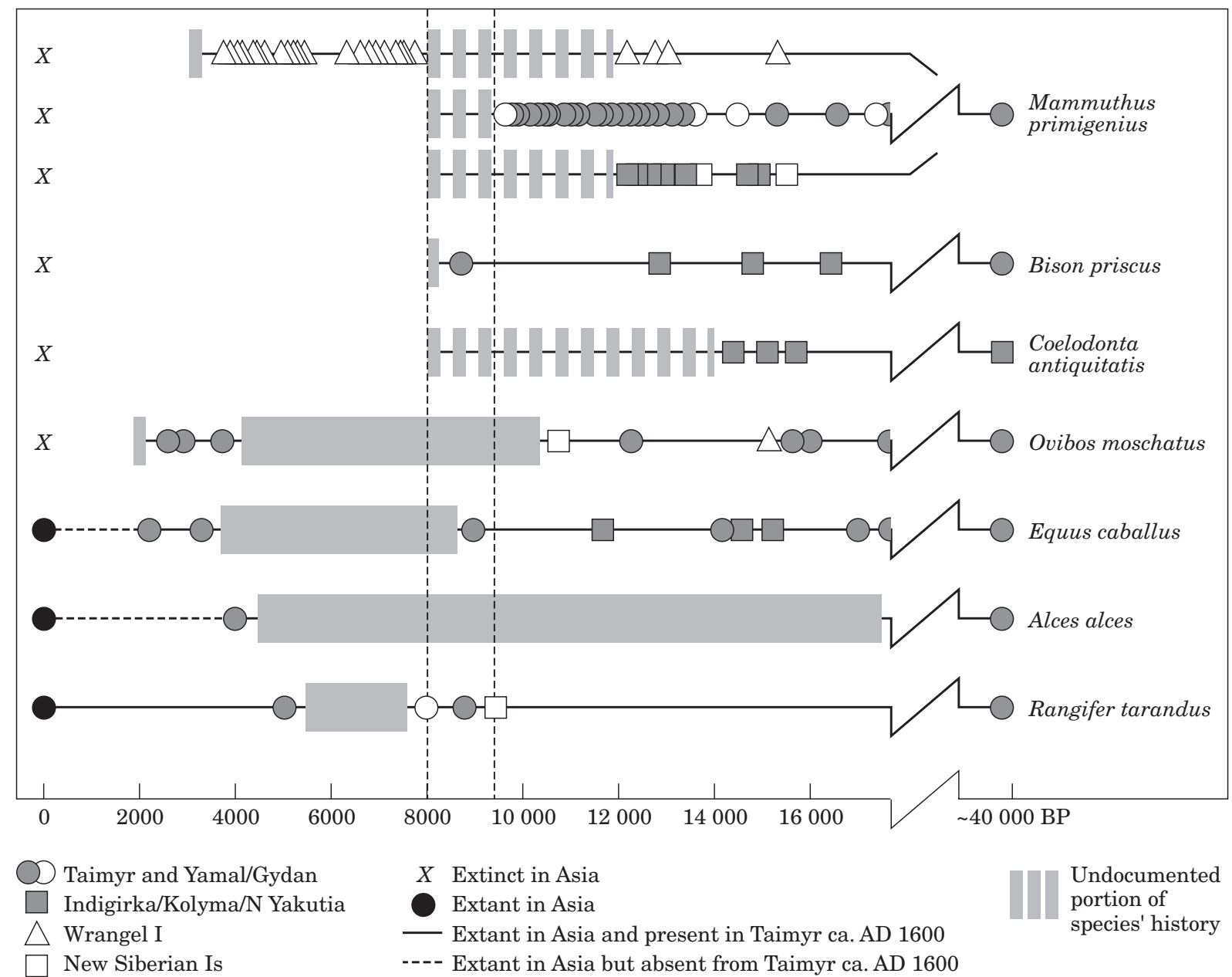

Figure 6. Chronometric summary of dates for seven megafaunal taxa, high Arctic periphery of Asia, post-18,000 yr BP (dating from various sources; see Table 4). Number of independent dates per species per area varies greatly. For Mammuthus primigenius, the post-18,000 yr BP dating framework is truly dense only for the Taimyr Peninsula and Wrangel Island, and to a lesser degree for the Kolyma, Indigirka, and northern Yakutia region. For all other taxa and regions, the number of records is much smaller. Date representation is not exhaustive, although it is believed that all currently available "last occurrence" dates for listed taxa have been included. To simplify presentation, each symbol has a constant width (representing mean date $\pm 2 \sigma$, where $\sigma$ is normalized to 100 years). With specific regard to Taimyr, all taxa except Coelodonta antiquitatis are confirmably present early in the radiocarbon record ( $>30,000 \mathrm{yr} \mathrm{BP})$.

The regional radiocarbon records of all Asian high Arctic megafauna show significant interruptions, most of which can be ascribed to low sampling effort. However, regional records also show that at least some populations of all megafaunal taxa managed to persist into the last two millennia or so of the Pleistocene. After this, areal records tend either to stop or to enter a lengthy hiatus, only to start again deep with the Holocene.

Grey boxes or screens on each species' time line represents undocumented portions of their histories (dashed if species is completely extinct, solid if still extant in at least part of its range). It should be noted that, although the position of the screens imply that Mammuthus, Bison, and Coelodonta disappeared quasi-simultaneously, as present there is no empirical evidence for this.

Species and populations generally thought to have become extinct close to the PHB: populations of Mammuthus primigenius living in areas other than Wrangel Island; Bison priscus; and Coelodonta antiquitatis. Species and populations that survived into the Holocene, as established by post-PHB records: Wrangel Island mammoths, Ovibos moschatus, Equus caballus, Alces alces, and Rangifer tarandus. There are no dating records for Ovibos moschatus, Equus caballus, or Alces alces for most or all of the first half of the Holocene. When late Holocene O. moschatus and $E$. caballus became locally extinct in northern Asia is not known, except that it must have occurred after $c .2000 \mathrm{yr}$ BP but before $400 \mathrm{yr}$ BP (time of first Russian penetration; Holland, 1994).

The later Holocene record is quite different: either megafaunal species do not appear at all, or reappear only after a lengthy hiatus. Previously, this point was usually considered of interest only in relation to the extinct megafauna, such as Mammuthus primigenius, Coelodonta antiquitatis, and Bison priscus, which do not, of course, reappear in mainland dating records after the close of the Pleistocene or earliest Holocene. But total loss is obviously not the only pattern present. This is especially noteworthy in the case of Ovibos moschatus and Equus caballus. At least according to the existing record, their chronologies enter a hiatus near the PHB that lasts until c. $4000 \mathrm{yr}$ BP, when they restart almost simultaneously. Although insufficient sampling 
could be an explanation for the gap, these two species have been the subject of a significant amount of collecting and radiocarbon dating. If there is a sampling bias, it is unexpected that it would take essentially the same form in two quite different species.

In seeking to offer an explanation for the early Holocene gap in megafaunal records, it is useful to turn to the evidence for the best investigated species, Mammuthus primigenius. The empirical record for this species ends permanently $c$. 10,000 $\mathrm{yr}$ BP in all mainland areas in which mammoths are known to have survived into the end-Pleistocene. In view of the large number of radiocarbon dates for this species, this conclusion may be considered very highly corroborated. The one known regional exception is Wrangel Island, but even here the record is not continuous. As may be seen in Figure 6, mammoths persisted on Wrangel until about 12,000 yr BP; at this point the local record stops. Then, after a substantial hiatus, the chronology begins again $c .7700 \mathrm{yr}$ BP and continues to c. 3700 yr BP (Vartanyan et al., 1993; Sulerzhitsky \& Romanenko, 1999). It needs to be emphasized that the end-Pleistocene gap in the Wrangel mammoth record is one of the best supported in late Quaternary paleontology, thanks to the large number of dates generated by different researchers in order to test the original claim of survival of Mammuthus into the Holocene (cf. Martin \& Stuart, 1995). Collecting conditions on Wrangel precisely parallel those in Taimyr and are just as stochastic, because virtually all finds are made at surface and can be of any age (R. MacPhee, pers. obs.). Indeed, when looked at from within the Pleistocene, the Wrangel record is very much like that of the New Siberian Islands or Yakutia, with "last" occurrence dates hovering around $12,000 \mathrm{yr}$ BP.

If woolly mammoths locally disappeared on Wrangel for a time, from what source population was the island recolonized? More generally, if the hiatus near the PHB affected mammoths, were the other megafauna affected similarly? If they were, then there is a clear implication: there was probably a common cause, because the probability of several longestablished mammalian species disappearing within 1000 years of each other (or less) is otherwise highly improbable. How, then, can these diverse facts and inferences be harmonized?

\section{Widespread megafaunal collapse at the Pleistocene- Holocene boundary?}

One explanation, which should be testable through a program of intensive investigations, is that there was an event at the end of the Pleistocene or earliest Holocene that led to the virtual disappearance of large mammals throughout northern Asia. Here we are referring not only to megafaunal extinctions-which have long been notionally linked to the Pleistocene/ Holocene transition - but also to extirpations, that is, to major population crashes among those species that did not become extinct at this time. As to what this event might have entailed, we can offer no resolution here because we disagree among ourselves regarding its probable nature. Marked climate change in western North America during roughly the same timespan eventually induced dramatic faunal changes in that area, as Grayson (2000) has recently detailed. However, the northern Eurasian event could have exerted its main effect within a very short period-probably much less than the broad interval (9500-8000 yr BP) depicted in Figure 6, which is exclusively modelled on "last" occurrence data-and need not have been climatic in nature. (The bibliography provides references to a number of recent papers on the causation of late Quaternary extinctions, to which the reader is referred.)

Central to our hypothesis is the idea that catastrophe was followed by recovery-in some cases. We hypothesize that in one or more refugial areas, the location of which is currently unknown or cannot yet be identified as such, survivors managed to persist after most of their conspecifics died out. These provided the stock for later repopulation of abandoned ranges. The speed and success of recovery evidently varied. This would be consonant with modern experience with differential recovery responses in species and communities that have been affected by extreme population variability (Vucetich et al., 2000; Jackson et al., 2001). Among species known to have survived into the Holocene, mammoths appear to have made the most limited recovery, repopulating Wrangel Island only from some unknown (but presumably mainland) source. The woolly rhino, whose last records are exclusively Pleistocene, evidently did not recover at all. It may or may not be relevant that, alone among the species-level taxa discussed here, Coelodonta had no populations or sister species in the New World (and therefore no hope of recolonization from that source). The record for moose is too inconsiderable for comment.

Other species did better. If Ovibos moschatus and Equus caballus recovered earlier than $c .4000 \mathrm{yr}$ BP in northern Asia, they must have done so in areas or during intervals for which there is as yet no radiocarbon coverage. Both were gone soon thereafter, at least from northern Siberia. Whether humans played any direct role in either their reintroduction or their demise is not known.

The extremely late date for Bison priscus $(8860 \pm$ $40 \mathrm{yr} \mathrm{BP})$ noted in Table 1 is perched on the cusp of the assumed rarefaction event. The plausibility of $B$. priscus having died out later than usually thought is marginally increased by Stuart's $(1991,1999)$ observation that several "survivor" taxa made it through the end-Pleistocene only to suffer local extirpation or range contraction shortly thereafter (e.g., disappearance of Equus caballus from Britain and Dama dama from northern and central Europe). Yet another example is offered by the giant Irish deer, Megaloceros giganteus, recently shown to 
have persisted on the Isle of Man and in Scotland until c. 9200 yr BP (Gonzalez et al., 2000).

The one exception to the scenario of PHB faunal collapse may be Rangifer tarandus. There is a late record for this species on the Yamal Peninsula at $7990 \pm 70 \mathrm{yr}$ BP (GIN-293), followed by one for the Bol'shaya Balakhnya valley at $5090 \pm 80 \mathrm{yr}$ BP (GIN3132; Sulerzhitsky \& Romanenko, 1997). It may be that the supposed rarefaction event did not affect reindeer, although with so few dates available for this species no conclusion is possible at this time. However, there are other records for Rangifer, from Svalbard and Franz Josef Land, that have an indirect bearing on the problem. Van Der Knaap (1989) and Forman et al. (2000) have reported dates as old as $6400 \mathrm{cal}$ yr BP on reindeer fecal pellets and shed antlers collected from these islands. Neither area has produced dates that relate to the first half of the Holocene. Seeking to explain this for the Franz Josef Land record, Forman et al. (2001) stated that only the best-preserved antlers were selected for dating purposes for their study, and that through happenstance older remains may not have been sampled. We suspect that one's ability to selectively control for age on the basis of preservation alone would be no better in Franz Josef Land than in Taimyr. It is quite plausible that reindeer were simply absent from these islands during the first half of the Holocene, although whether this happened in correlation with mainland events or independently cannot be evaluated at present.

Of additional interest is the fact that the reindeer dates from Franz Josef Land terminate $c .1300 \mathrm{cal}$ yr $\mathrm{BP}$, and there are no historical records (i.e., none since the archipelago's generally accepted date of discovery in 1873 (Holland, 1993)). In combination, these data seem to indicate that, not unexpectedly, reindeer were subject to "normal" population crashes/expansions/ recolonizations, especially in the more marginal parts of their distributions. But there was always some place where they managed to survive and carry on. Thus the real paradox posed by reindeer and the other remaining high Arctic megafauna is not that they in particular were survivors, but that so few others were.

In conclusion, the possibility that the megafauna of northern Eurasia were affected by an event at or near the PHB, resulting in complete species-level losses in some instances and widespread populational collapses in others, adds an important nuance to the continuing debate concerning the nature and cause of Late Quaternary extinctions. This scenario may be tested by dating programs that not only search for "last" occurrences, but that also compare dating records of different taxa in different affected areas. For falsification purposes, a much larger megafaunal date pool than exists at present may show that populations of different species did not undergo coordinated disappearances across wide areas of northern Asia at or near the PHB, or that the record of presence/absence is too variable to admit any common cause. Although it might be argued that there could be a geophysical explanation for the pattern of radiocarbon dates around the PHB, the only one proposed to date - radical change in the atmospheric concentration of carbon dioxide in the high Arctic (Sulerzhitsky, 1997) - lacks a plausible mechanism. Molecular evidence may also be marshalled to establish whether or not Holocene populations were genetically continuous with their Pleistocene precursors across the critical period. Clearly, much remains to be learned about the dynamics of megafaunal extinction and persistence in the far north.

\section{Acknowledgements}

We are grateful to Prof. N. Vereshchagin, Prof. V. Ukraintseva, Dr R.-D. Kahlke, and Dr Antoni Alcover for stimulating discussions on several of the topics raised in this paper. Dr Paul Martin read an earlier draft of this paper, and as always we are grateful for his insights and encouragement. This paper benefitted from the thoughts and criticisms of three reviewers, one of whom was the not-so-anonymous Dr Don Grayson. We thank Mr Bernard Buigues, general director of the Cerpolex/Mammuthus Expedition, for his generous support of our research programme (including the provision of funds for most of the dates published here), and the staff of the Taimyr Nature Reserve for help with all aspects of our work. The excellent maps were drawn by Patricia Wynne and crucial editorial help was provided by Ruth O'Leary. Aspects of this research were supported by the Irene Diamond Fund (to R.M.) and NSF OPP 0117400 (to R.M., A.G., and Rob DeSalle).

\section{References}

Alroy, J. (2001). A multispecies overkill simulation of the endPleistocene megafaunal mass extinction. Science 292, 1893-1896.

Agenbroad, L. D. (1984). New World mammoth distribution. In (P. S. Martin \& R. G. Klein, Eds) Quaternary Extinctions: A Prehistoric Revolution. Tucson: University of Arizona Press, pp. 90-108.

Beck, M. W. (1996). On discerning the cause of late Pleistocene megafaunal extinctions. Paleobiology 22, 91-103.

Beck, W. J., Richards, D. A., Edwards, R. L., Silverman, B. W., Smart, P. L., Donahue, D. L., Hererra-Osterheld, S., Burr, G. S., Calsoyas, L., Jull, A. J. T. \& Biddulph, D. (2001). Extremely large variations of atmospheric ${ }^{14} \mathrm{C}$ concentration during the last glacial period. Science 292, 2453-2458.

Belov, M. I. (1956). History of the discovery and development of the Northern Sea Route, vol. 1, Arctic seafaring from ancient times to the mid-nineteenth century. Leningrad: Izdatel'stvo 'Morskoy Transpot' (in Russian).

Berger, J., Swenson, J. E. \& Persson, I.-L. (2001). Recolonizing carnivores and naive prey: Conservation lessons from Pleistocene extinctions. Science 291, 1036-1039.

Bjornstad, O. N. \& Grenfell, B. T. (2001). Noisy clockwork: time series analysis of population fluctuations in animals. Science $\mathbf{2 9 3}$ 638-643.

Culver, M., Johnson, W. E., Pecon-Slattery, J. \& O’Brien, S. J. (2000). Genomic ancestry of the American puma (Puma concolor). Journal of Heredity 91, 186-197.

Ermolova, N. (1978). Theriofauna of Angara valley in the Late Anthropogene. Novosibirsk: 'Nauka' (in Russian). 
Faunmap Working Group (1996). Spatial response of mammals to late Quaternary environmental fluctuations. Science 272, 16011606.

Fiedel, S. J. (1999). Older than we thought: Implications of corrected dates for Paleoindians. American Antiquity 64, 95-115.

Fisher, D. A. (1996). Extinction of proboscideans in North America. In (J. Shoshani \& P. Tassy, Eds) The Proboscidea: Evolution and Palaeoecology of Elephants and their Relatives. New York: Oxford University Press, pp. 296-315.

Forman, S. L., Lubinski, D. \& Weihe, R. R. (2000). The Holocene occurrence of reindeer on Franz Josef Land, Russia. The Holocene 10, 763-768.

Forstén, A.-M. (1988). The small caballoid horse of the upper Pleistocene and Holocene. Journal of Animal Breeding Genetics 105, 161-176.

Geyh, M. \& Schleicher, H. (1991). Absolute Age Determination. New York: Springer-Verlag.

Gonzalez, S., Kitchener, A. C. \& Lister, A. M. (2000). Survival of the Irish elk into the Holocene. Nature 405, 753-754.

Graham, R. W. \& Lundelius, E. L. (1984). Coevolutionary disequilibrium and Pleistocene extinctions. In (P. S. Martin \& R. G. Klein, Eds) Quaternary Extinctions: A Prehistoric Revolution. Tucson: University of Arizona Press, pp. 223-249.

Grayson, D. K. (2000). Mammalian responses to middle Holocene climate change in the Great Basin of the western United States. Journal of Biogeography 27, 181-192.

Grayson, D. K. (2001). The archaeological record of human impacts on animal populations. J. World Prehistory 15, 1-68.

Greenwood, A. D., Lee, F., Capelli, C., DeSalle, R., Marx, P. A. \& MacPhee, R. D. E. (2001). Evolution of endogenous retroviral-like elements of the woolly mammoth (Mammuthus primigenius) and its relatives. Molecular Biology and Evolution 18, 840-847.

Grosswald, M. G. (1998). Late-Weichselian ice sheets in Arctic and Pacific Siberia. Quaternary International 45/46, 3-18.

Grosswald, M. G. \& Hughes, T. J. (1999). The case for an ice-shelf in the Pleistocene Arctic Ocean. Polar Geography and Geology 23, 23-54.

Guthrie, R. D. (1990). Frozen Fauna of the Mammoth Steppe: the Story of Blue Babe. Chicago: University of Chicago Press.

Harington, C. R. (1970). A postglacial muskox (Ovibos moschatus) from Grandview, Manitoba, and comments on the zoogeography of Ovibos. National Museums of Canada Publications in Paleontolology 2, 1-8.

Holland, C. (1994). Arctic Exploration and Development, c. 500 B.C. to 1915: An Encyclopedia. New York: Garland Publishing.

Jackson, J. B. C., et al. (2001). Historical overfishing and the recent collapse of coastal ecosystems. Science 293, 629-637.

Kahlke, R.-D. (1994). Die Entstehungs-, Entwicklungs- und Verbreitungsgeschichte des oberpleistozänen Mammuthus-CoelodontaFaunenkomplexes in Eurasien (Grosssäuger). Abhandlungen Senckenbergische Naturforschende Gesellschaft 546, 1-164.

Kahlke, R.-D. (1999). The history of the origin, evolution and dispersal of the late Pleistocene Mammuthus-Coelodonta faunal complex in Eurasia (large mammals). Rapid City, SD: Fenske Co.

Kitagawa, H. \& van der Plicht, H. (1998). Atmospheric radiocarbon calibration to 45,000 yr B.P.: Late glacial fluctuations and cosmogenic isotope production. Science 279, 1187-1190.

Kromer, B. \& Spurk, M. (1998). Revision and tentative extension of the tree-ring based calibration, 9,200-11,855 cal BP. Radiocarbon 40, 1117-1125.

Kurtén, B. \& Anderson, E. (1980). Pleistocene Mammals of North America. New York: Columbia University Press.

Kuzmin, Y. V. \& Tankersley, K. B. (1996). The colonization of eastern Siberia: an evaluation of the Paleolithic Age radiocarbon dates. Journal of Archaeological Science 23, 577-585.

Kuznetsova, T. V., Sulerzhitsky, L. D., Siegert, C. \& Schirrmeister, L. (2001). New data on the "mammoth" fauna of the Laptev Shelf Land (Arctic Siberia). In (G. Cavarretta, P. Giola, M. Mussi \& M. R. Palombo, Eds) La Terra degli ElefantilThe World of Elephants. Proceedings of the 1st International Congress, Rome, 16-20 October 2001, pp. 289-292.
Lent, P. C. (1996). More on muskoxen [comment on Spassov, 1991]. Cryptozoology 12, 91-94.

Lent, P. C. (1999). Muskoxen and their Hunters. Norman: University of Oklahoma Press.

Lister, A. M. (1993). Mammoths in miniature. Science 362, 288-289.

Long, A. \& Rippeteau, B. (1974). Testing contemporaneity and averaging radiocarbon dates. American Antiquity 39, 205-221.

Long, A., Martin, P. S. \& Lagiglia, H. A. (1998). Ground sloth extinction and human occupation at Gruta del Indio, Argentina. Radiocarbon 40, 693-700.

MacPhee, R. D. E. \& Flemming, C. (1999). Requiem aeternum: The last five hundred years of mammalian species extinctions. In (R. D. E. MacPhee, Ed.) Extinctions in Near Time: Causes, Contexts, and Consequences. New York: Kluwer Academicl Plenum Publishers, pp. 333-372.

MacPhee, R. D. E. \& Flemming, C. (2001). Extinction: Complexity of assessing risk. Science 292, 217.

MacPhee, R. D. E. \& Marx, P. A. (1997). The 40,000-year plague: Humans, hyperdisease, and first-contact extinctions. In (S. M. Goodman \& B. D. Patterson, Eds) Natural Change and Human Impact in Madagascar. Washington, D.C.: Smithsonian Institution Press, pp. 169-217.

MacPhee, R. D. E., Flemming, C. \& Lunde, D. (1999). "Last occurrence" of the Antillean insectivore Nesophontes: New radiometric dates and their interpretation. American Museum Novitates 3264, 1-19.

Martin, P. S. \& Guilday, J. E. (1967). A bestiary for Pleistocene biologists. In (P. S. Martin \& R. G. Klein, Eds) Quaternary Extinctions: A Prehistoric Revolution. Tucson: University of Arizona Press, pp. 1-62.

Martin, P. S. \& Steadman, D. W. (1999). Prehistoric extinctions on islands and continents. In (R. D. E. MacPhee, Ed.) Extinctions in Near Time: Causes, Contexts, and Consequences. New York: Kluwer Academic/Plenum Publishers, pp. 17-56.

Martin, P. S. \& Stuart, A. J. (1995). Mammoth extinction: Two continents and Wrangel Island. Radiocarbon 37, 7-10.

McFarlane, D. A. (1999). A comparison of methods for the probabilistic determination of vertebrate extinction chronologies. In (R. D. E. MacPhee, Ed.) Extinctions in Near Time: Causes, Contexts, and Consequences. New York: Kluwer Academicl Plenum Publishers, pp. 95-103.

Mol, D., Coppens, Y., Tikhonov, A. N., Agenbroad, L. D., MacPhee, R. D. E., Flemming, C., Greenwood, A., Buigues, B., Marliave, C. de, van Geel, B., van Reenen, G. B. E., Pals, J. P., Fisher, D. C. \& Fox, D. (2001a). The Jarkov Mammoth: 20,000year-old carcass of a Siberian woolly mammoth Mammuthus primigenius (Blumenbach, 1799). In (G. Cavarretta, P. Giola, M. Mussi \& M. R. Palombo, Eds) La Terra degli Elefanti/The World of Elephants. Proceedings of the 1st International Congress, Rome, 16-20 October 2001, pp. 305-309.

Mol, D., Tikhonov, A. N., MacPhee, R. D. E., Flemming, C., Buigues, B., Marliave, C. de, Coppens, Y. \& Agenbroad, L. D. (2001b). The Fishhook Mammoth: rediscovery of a woolly mammoth carcass by the CERPOLEX/ Mammuthus Team, Taimyr Peninsula, Siberia. In (G. Cavarretta, P. Giola, M. Mussi \& M. R. Palombo, Eds) La Terra degli ElefantilThe World of Elephants. Proceedings of the 1st International Congress, Rome, 16-20 October 2001pp. 310-313.

Möller, P., Bolshiyanov, D. Yu. \& Bergsten, H. (1999). Weichselian geology and paleoenvironmental history of the central Taymyr Peninsula, Siberia, indicating no glaciation during the last global glacial maximum. Boreas 28, 92-114.

Orlova, L. A., Kuzmin, Y. V. \& Zolnikov, I. D. (2000). Time-space systematics for mammoths (Mammuthus primigenius Blum.) and prehistoric humans in Siberia (on the basis of radiocarbon dating). Archaeology, Ethnology \& Anthropology of Eurasia 3, 31-41.

Pitul'ko, V. V. (2001). Terminal Pleistocene-Early Holocene occupation in northeast Asia and the Zhukhov assemblage. Quaternary Science Reviews 20, 267-275.

Reumer, J. U. W. F. \& Mol, D. (2001). The myth of the pygmy mammoth. Abstract volume, "World Islands in Prehistory," September 13-18, 2001. 
Rusanov, B. S. (1968). Biostratigraphy of the Cenozoic Deposits of Southern Yakutia. Moscow: Izd-vo 'Nauka' (in Russian).

Sher, A. V. (1974). Pleistocene mammals and stratigraphy of the Far Northeast USSR and North America. International Geology Review 16, 1-284.

Shipman, P. (1981). Life History of a Fossil. Cambridge, Massachusetts: Harvard University Press.

Siegert, M. J. \& Marsiat, I. (2001). Numerical reconstructions of LGM climate across the Eurasian Arctic. Quaternary Science Reviews 20, 1595-1605.

Signor, P. W. \& Lipps, J. H. (1982). Sampling bias, gradual extinction patterns, and catastrophes in the fossil record. Special Papers of the Geological Society of America 190, 291-296.

Spassov, N. (1991). The musk ox in Eurasia: extinct at the Pleistocene-Holocene boundary or survivor to historical times? Cryptozoology 10, 4-15.

Stuart, A. (1991). Mammalian extinctions in the late Pleistocene of northern Eurasia and North America. Biological Reviews 66, 453-562.

Stuart, A. (1999). Late Pleistocene megafaunal extinctions: a European perspective. In (R. D. E. MacPhee, Ed.) Extinctions in Near Time: Causes, Contexts, and Consequences. New York: Kluwer Academic/Plenum Publishers, pp. 257-270.

Stuiver, M., Reimer, P. J., Bard, E., Beck, J. W., Burr, G. S., Hughen, K. A., Kromer, B., McCormac, G., van der Plicht, J. \& Spurk, M. (1998). INTCAL98 radiocarbon age calibration: 24,000-0 cal BP. Radiocarbon 40, 1041-1084.

Sulerzhitsky, L. D. (1995). Features of the radiocarbon chronology of mammoths (Mammuthus primigenius) from Siberia and northeastern Europe. Proceedings of the Zoological Instititute of the USSR Academy of Sciences 263, 163-182 (in Russian).

Sulerzhitsky, L. D. (1997). Peculiarities of radiocarbon chronology of Younger Dryas deposits in the Taymyr Peninsula. Quaternary International 41/42, 119-123.

Sulerzhitsky, L. D. \& Romanenko, F. A. (1997). Age and distribution of the "mammoth" fauna of the polar region of Asia (according to radiocarbon data). Kriosfera zemli 1, 12-19 (in Russian).

Sulerzhitsky, L. D. \& Romanenko, F. A. (1999). The "twilight" of the mammoth fauna in the Asiatic Arctic. Ambio 28, 251-255.

Tikhonov, A. N. (1998). The finds of muskox on the territory of the former USSR. In (J. Saunders, B. Styles \& G. Baryshnikov, Eds) Quaternary Paleozoology in the Northern Hemisphere, Papers of the Illinois State Museum 27, pp. 211-226.

Tikhonov, A. N. (1999). Distribution of Pleistocene bison (Bison priscus) in Siberian human sites. In (J.-P. Brugal, F. David, J. Enloe \& J. Jaubert, Eds) Le Bison: Gibier et moyen de subsistance des hommes du Paléolithique aux Paléoindiens des Grandes Plaines, Actes du colloque international, Toulouse, 6-10 juin 1995. Antibes: Editions APDCA, pp. 367-372

Todd, L. C. \& Frison, G. C. (1986). Taphonomic study of the Colby Site mammoth bones. In (G. C. Frison \& L. C. Todd, Eds) The Colby Mammoth Site: Taphonomy and Archaeology of a Clovis Kill in Northern Wyoming. Albuquerque: University of New Mexico Press, pp. 27-90.

Van der Knaap, W. O. (1989). Past vegetation and reindeer on Edgeoya (Spitsbergen) between c. 7900 and c. 3800 BP studied by means of peat layers and reindeer fecal pellets. Journal of Biogeography 16, 379-394.

Van der Plicht, J. (1998). Radiocarbon calibration: Towards the complete dating range. In Actes du colloque: C14 archéologie. Paris: CNRS, pp. 73-77.

Van der Plicht, J. (2000). Introduction: The 2000 Radiocarbon varve/comparison issue. Radiocarbon 42, 313-322.

Vartanyan, S. L., Garutt, V. E. \& Sher, A. V. (1993). Holocene dwarf mammoths from Wrangel Island in the Siberian Arctic Nature 362, 337-340.

Vartanyan, S. L., Arslanov, Kh. A., Tertychnaya, T. V. \& Chernov, S. B. (1995). Radiocarbon dating evidence for mammoths on Wrangel Island, Arctic Ocean, until 2000 BC. Radiocarbon 37, $1-6$.

Vasil'chuk, Yu. K., Punning, J.-M. \& Vasil'chuk, A. (1997). Radiocarbon ages of mammoths in northern Eurasia: Implications for population development and late Quaternary environment. Radiocarbon 39, 1-18.

Vereshchagin, N. K. (1971). Prehistoric hunting and the extinction of Pleistocene mammals in the USSR [in Russian]. Proceedings of the Zoological Instititute of the USSR Academy of Sciences 69 , 200-232.

Vereshchagin, N. K. \& Baryshnikov, G. F. (1984). Quaternary mammalian extinctions in northern Eurasia. In (P. S. Martin \& R. G. Klein, Eds) Quaternary Extinctions: A Prehistoric Revolution. Tucson: University of Arizona Press, pp. 483-516.

Vereshchagin, N. K. \& Tikhonov, A. N. (1999). Exterior of the mammoth. Cranium 16(1), $4-43$.

Vilà, C., Leonard, J. A., Götherström, A., Marklund, S., Sandberg, K., Lidén, K., Wayne, R. K. \& Ellegren, H. (2001). Widespread origins of domestic horse lineages. Science 29, 474-477.

Vucetich, J. A., Waite, T. A., Qvarnemark, L. \& Ibargüen, S. (2000). Population variability and extinction risk. Conservation Biology 14, 1704-1714.

Yokoyama, Y., Esat, T. M., Lambeck, K. \& Fifield, L. K. (2000). Last Ice Age millennial scale climate changes recorded in Huon Peninsula corals. Radiocarbon 42, 383-401. 